\title{
IMMUNOBIOLOGY
}

\section{Comparison of primary human cytotoxic T-cell and natural killer cell responses reveal similar molecular requirements for lytic granule exocytosis but differences in cytokine production}

\author{
*Samuel C. C. Chiang, ${ }^{1}$ *Jakob Theorell, ${ }^{1}$ Miriam Entesarian, ${ }^{2,3}$ Marie Meeths,,${ }^{2,3}$ Monika Mastafa, ${ }^{2,3}$ Waleed Al-Herz, ${ }^{4}$ \\ Per Frisk, ${ }^{5}$ Kimberly C. Gilmour, ${ }^{6}$ Marianne Ifversen, ${ }^{7}$ Cecilia Langenskiöld, ${ }^{8}$ Maciej Machaczka, ${ }^{9}$ Ahmed Naqvi, ${ }^{10,11}$ \\ Jeanette Payne, ${ }^{12}$ Antonio Perez-Martinez, ${ }^{13}$ Magnus Sabel, ${ }^{8}$ Ekrem Unal, ${ }^{14}$ Sule Unal, ${ }^{15}$ Jacek Winiarski, ${ }^{16}$ \\ Magnus Nordenskjöld, ${ }^{3}$ Hans-Gustaf Ljunggren, ${ }^{1}$ Jan-Inge Henter, ${ }^{2}$ and Yenan T. Bryceson ${ }^{1,17}$
}

\begin{abstract}
${ }^{1}$ Centre for Infectious Medicine, Department of Medicine, Karolinska Institutet, Karolinska University Hospital Huddinge, Stockholm, Sweden; ${ }^{2} \mathrm{Childhood} \mathrm{Cancer}$ Research Unit, Department of Women's and Children's Health, Karolinska Institutet, Karolinska University Hospital Solna, Stockholm, Sweden; ${ }^{3}$ Clinical Genetics Unit, Department of Molecular Medicine and Surgery, and Center for Molecular Medicine, Karolinska Institutet, Karolinska University Hospital Solna, Stockholm, Sweden; ' 4 Department of Pediatrics, Faculty of Medicine, Kuwait University, Kuwait City, Kuwait; ${ }^{5}$ Department of Women's and Children's Health, Uppsala University, Uppsala, Sweden; 6 Immunology Laboratory, Great Ormond Street Hospital, London, United Kingdom; ' 7 Department of Pediatrics,

Copenhagen University Hospital, Rigshospitalet, Copenhagen, Denmark; ${ }^{8}$ Department of Women's and Children's Health, University of Gothenburg, The Queen Silvia Children's Hospital, Gothenburg, Sweden; ${ }^{9}$ Division of Hematology, Department of Medicine, Karolinska Institutet, Karolinska University Hospital Huddinge, Stockholm, Sweden; ${ }^{10}$ Aga Khan University, Karachi, Pakistan; ${ }^{11}$ Hospital for Sick Children, Toronto, ON; ${ }^{2}$ Sheffield Children's Hospital, Sheffield, United Kingdom; ${ }^{13}$ Division of Pediatric Hematology-Oncology, Hospital Infantil Universitario Niño Jesús, Madrid, Spain; ${ }^{14}$ Division of Pediatric Hematology-Oncology, Department of Pediatrics, Erciyes University, Kayseri, Turkey; ${ }^{15}$ Division of Pediatric Hematology, Hacettepe University, Ankara, Turkey; ${ }^{16}$ Departments of Pediatrics and of Clinical Science Intervention and Technology, Karolinska Institutet, Karolinska University Hospital Huddinge, Stockholm, Sweden; and ${ }^{17}$ Broegelmann Research Laboratory, The Gades Institute, University of Bergen, Bergen, Norway
\end{abstract}

\section{Key Points}

- Compared with cytotoxic T cells, NK cells share mechanisms for lytic granule release but more stringently control cytokine production.

- Analysis of CD57bright cytotoxic T-cell function may prove useful in the diagnosis of primary immunodeficiencies.

Cytotoxic lymphocytes, encompassing cytotoxic T lymphocytes (CTLs) and natural killer (NK) cells, kill pathogen-infected, neoplastic, or certain hematopoietic cells through the release of perforin-containing lytic granules. In the present study, we first performed probability-state modeling of differentiation and lytic granule markers on $\mathrm{CD8}^{+} \mathrm{T}$ cells to enable the comparison of bona fide CTLs with NK cells. Analysis identified CD57bright expression as a reliable phenotype of granule marker-containing CTLs. We then compared $\mathrm{CD} 3{ }^{+} \mathrm{CD} 8+\mathrm{CD} 57$ bright $\mathrm{CTLs}$ with NK cells. Healthy adult peripheral blood $\mathrm{CD}^{+}{ }^{+} \mathrm{CD} 8{ }^{+} \mathrm{CD} 57$ bright $\mathrm{CTLs}$ expressed more granzyme $\mathrm{B}$ but less perforin than $\mathrm{CD}_{3}-\mathrm{CD} 56^{\mathrm{dim}}$ NK cells. On stimulation, such CTLs degranulated more readily than other T-cell subsets, but had a propensity to degranulate that was similar to NK cells. Remarkably, the CTLs produced cytokines more rapidly and with greater frequency than NK cells. In patients with biallelic mutations in UNC13D, STX11, or STXBP2 associated with familial hemophagocytic lymphohistiocytosis, CTL and NK cell degranulation were similarly impaired. Therefore, cytotoxic lymphocyte subsets have similar requirements for Munc13-4, syntaxin-11, and Munc18-2 in lytic granule exocytosis. The present results provide a detailed comparison of human $\mathrm{CD}^{+}{ }^{+} \mathrm{CD} 8+\mathrm{CD} 57^{\text {bright }} \mathrm{CTLs}$ and NK cells and suggest that analysis of CD57bright $\mathrm{CTL}$ function may prove useful in the diagnosis of primary immunodeficiencies including familial hemophagocytic lymphohistiocytosis. (Blood. 2013;121(8):1345-1356)

\section{Introduction}

Subsets of T cells and natural killer (NK) cells have the capacity to kill pathogen-infected, neoplastic, and certain hematopoietic cells through the targeted release of perforin and granzymes from lytic granules. On release, perforin forms pores in the target cell membrane, facilitating entry of apoptosis-inducing granzymes..$^{1,2}$ Most perforin-expressing, cytotoxic T lymphocytes (CTLs) recognize target cells using somatically rearranged, clonally distributed
TCRs that bind specific MHC class I/peptide complexes on target cells. ${ }^{3}$ Accordingly, such CTLs express the CD8 coreceptor for MHC class I. Complementing T cell-mediated immunity, NK cells recognize target cells using numerous germline-encoded activation receptors, with such recognition being potentiated by the loss of MHC class I expression on target cells. ${ }^{4,5}$ In addition to cytotoxicity, another important function of cytotoxic lymphocytes is the
Submitted July 11, 2012; accepted November 12, 2012. Prepublished online as Blood First Edition paper, January 2, 2013; DOI 10.1182/blood-2012-07-442558.

${ }^{\star}$ S.C.C.C. and J.T. contributed equally to this work.

The online version of this article contains a data supplement.
The publication costs of this article were defrayed in part by page charge payment. Therefore, and solely to indicate this fact, this article is hereby marked "advertisement" in accordance with 18 USC section 1734. 
production of chemokines and cytokines such as TNF- $\alpha$ and IFN- $\gamma$, which promote immunity against intracellular pathogens. The signaling cascades controlling the variety of effector functions are perceived to be similar between CTLs and NK cells. ${ }^{6}$ However, in the mouse, in vitro and in vivo imaging studies have shown differences in how CTLs and NK cells recognize and eliminate target cells. ${ }^{7,8}$ Whereas CTLs form stable contacts with target cells, NK cells are more tentative and form transient contacts inducing less profound $\mathrm{Ca}^{2+}$ mobilization and cytoskeletal polarization. These observations may reflect differences in signaling and regulation. Therefore, meticulous comparisons of human CTLs and NK cells may provide insights into shared versus distinct mechanisms regulating their cytolytic and cytokine-mediated effector functions.

Defects in lymphocyte cytotoxic function are associated with often-fatal diseases. Subjects with biallelic nonsense mutations in the gene encoding perforin, $P R F 1$, typically develop hemophagocytic lymphohistiocytosis (HLH) in infancy. ${ }^{9} \mathrm{HLH}$ is a hyperinflammatory disorder characterized by unremitting fever, splenomegaly, hyperferritinemia, cytopenia, and sometimes hemophagocytosis. ${ }^{10-12}$ HLH caused by PRF1 mutations is termed familial HLH type 2 (FHL2). In addition, milder missense mutations in PRF1 may not cause $\mathrm{HLH}$, but are associated with hematologic malignancies later in life. ${ }^{13,14}$ In addition to $P R F 1$, biallelic mutations in $U N C 13 D$, $S T X 11$, and STXBP2 are associated with FHL3, FHL4, and FHL5, respectively. ${ }^{15-18}$ These genes encode the Munc13-4, syntaxin-11, and Munc18-2 proteins, respectively, which are required for critical steps in lytic granule exocytosis. ${ }^{15,17-19}$ Accordingly, defective NK cell cytotoxicity is a central criterion among the 8 diagnostic criteria for HLH (of which at least 5 must be fulfilled). ${ }^{20} \mathrm{~A}$ rapid diagnosis is imperative for the effective treatment of FHL. ${ }^{20}$ In the clinical setting, assays quantifying NK cell function have been useful for the diagnosis and discrimination of different FHL subtypes. ${ }^{19,21,22}$ In certain settings, for example, in patients with low frequencies of peripheral blood NK cells, assays that could quantify primary human T-cell degranulation would be useful.

To enable use of $\mathrm{T}$ cell-based functional analyses for clinical diagnostic purposes, a more detailed knowledge of CTL biology is required. Furthermore, through comparisons of primary human CTLs and NK cells, insights into molecular similarities and differences in cytotoxic lymphocyte subsets can also be gained. For such comparisons to be made, markers for the identification of bona fide CTLs, defined herein as differentiated, perforin-containing $\mathrm{CD}^{+} \mathrm{T}$ cells, are required. Highly cytotoxic, perforin-containing NK cells are typically defined as $\mathrm{CD}^{-} \mathrm{CD}^{-\mathrm{dim}}$ cells and constitute approximately $10 \%$ of PBMCs in adults. ${ }^{23}$ Many different subsets of $\mathrm{CD} 8^{+} \mathrm{T}$ cells circulate in the peripheral blood, representing distinct differentiation states. $^{24,25}$ Several markers have been used to distinguish these subsets. Among $\mathrm{CD}^{+} \mathrm{T}$ cells, naive cells are often defined as $\mathrm{CD}^{+}{ }^{+} \mathrm{CD} 27^{+} \mathrm{CD} 45 \mathrm{RA}^{+}$, memory cells as $\mathrm{CD} 8{ }^{+} \mathrm{CD} 45 \mathrm{RO}^{+}$, and effector cells as $\mathrm{CD}^{+}{ }^{+} \mathrm{CD} 27^{-} \mathrm{CD} 45 \mathrm{RA}^{+}{ }^{+26,27} \mathrm{In}$ addition to these defined subsets, the molecules CD56, CD57, and CD62L have been suggested as good markers for identifying CTLs. ${ }^{26,28,29}$ However, no consensus has been reached regarding the best phenotypic definition of CTLs. ${ }^{30}$

To obtain an unbiased view of $\mathrm{CD}^{+} \mathrm{T}$-cell lineage marker relationships, in the present study, we performed probability-state modeling of primary human cells with respect to expression of cytotoxic granule constituents and various lineage and differentiation markers. Our results identify bright expression of CD57 as a useful marker for the detection of CTLs in healthy subjects. Remarkably, functional analyses revealed that $\mathrm{CD} 3{ }^{+} \mathrm{CD} 8{ }^{+} \mathrm{CD} 57^{\text {bright }}$
CTLs display a similar propensity to degranulate and kill target cells as $\mathrm{CD}^{-}{ }^{-} \mathrm{CD} 56^{\mathrm{dim}} \mathrm{NK}$ cells. However, the subsets differed in the composition of their lytic granule content and in their propensity for the production of cytokines. In addition to delineating similarities and differences in the function of primary human CTLs and NK cells, our findings also provide a reproducible means for rapidly quantifying CTL degranulation, which may prove useful for the diagnosis of FHL and other primary immunodeficiencies.

\section{Methods}

\section{Patients and controls}

The study was approved by the Regional Ethical Review Board in Stockholm. Healthy controls were recruited from the Karolinska University Hospital blood bank. Written consent was obtained from the families of patients with confirmed biallelic mutations in PRF1, UNC13D, STX11, or $S T X B P 2$ in accordance with the Declaration of Helsinki.

\section{Cells}

Peripheral blood from healthy controls and patients was collected in heparin tubes and processed within 24 hours of venipuncture. PBMCs were obtained by density gradient centrifugation (Lymphoprep; Axis-Shield) and resuspended in complete medium (RPMI 1640 medium supplemented with $10 \%$ FBS, L-glutamine, penicillin, and streptomycin; all Hyclone). In some experiments, PBMCs were stimulated with $500 \mathrm{IU} / \mathrm{mL}$ of IL-2 (Proleukin; Novartis) for 36-48 hours. For cytotoxicity assays, $\mathrm{CD} 3{ }^{+} \mathrm{CD} 8^{+}$ T-cell subsets or $\mathrm{CD}^{-}{ }^{-} \mathrm{CD} 56^{+} \mathrm{NK}$ cells were isolated from PBMCs by negative selection using magnetic beads. $\mathrm{CD} 8^{+} \mathrm{T}$-cell subsets were isolated using a $\mathrm{CD}^{+}$T-cell isolation kit and then supplemented with antiCD45RO- and anti-CD57-coupled beads for naive T-cell isolation, with anti-CD45RA- and anti-CD57-coupled beads for memory CD8 ${ }^{+}$T-cell isolation, and with an anti-CD28 depletion kit for effector $\mathrm{CD} 8^{+}$T-cell isolation (all Miltenyi Biotec). NK cells were isolated using a NK cell isolation kit (Miltenyi Biotec). Purity of the isolated cell populations was checked by flow cytometry (naive T cells were $89 \% \pm 5 \%$ $\mathrm{CD}^{+}{ }^{+} \mathrm{CD} 8{ }^{+} \mathrm{CD} 45 \mathrm{RA}^{+} \mathrm{CD} 45 \mathrm{RO}^{-} \mathrm{CD}^{-} 7^{-}$cells, memory $\mathrm{T}$ cells were $85 \%$ $\pm 9 \% \mathrm{CD}^{+}{ }^{+} \mathrm{CD} 8^{+} \mathrm{CD}^{2} 5 \mathrm{RA}^{-} \mathrm{CD} 45 \mathrm{RO}^{+} \mathrm{CD} 57^{-}$cells, effector $\mathrm{T}$ cells were $82 \% \pm 16 \% \mathrm{CD}^{+}{ }^{+} \mathrm{CD} 8{ }^{+} \mathrm{CD} 45 \mathrm{RA}^{+} \mathrm{CD}^{+} 5 \mathrm{RO}^{-} \mathrm{CD}^{-} 7^{+}$cells, and NK cells were $96 \% \pm 2 \% \mathrm{CD}^{-}{ }^{-} \mathrm{CD} 56^{+}$cells). Isolated cells were resuspended in complete medium and used in assays the next day. The human erythroleukemia cell line K562 and the mouse mastocytoma cell line P815 (both from ATCC) were maintained in complete medium.

\section{Antibodies}

For cell staining and flow cytometry, fluorochrome-conjugated anti-CD3 (clone S4.1; Invitrogen), anti-CD4 (S3.5; Invitrogen), anti-CD8 (RPA-T8; BioLegend), anti-CD14 (M5E2; BD Biosciences), anti-CD19 (HIB19; BD Biosciences), anti-CD27 (M-T271; BD Biosciences), anti-CD28 (CD28.2; BioLegend), anti-CD45RA (MEM-56; Invitrogen), anti-CD45RO (UCHL1; Beckman Coulter), anti-CD56 (NCAM16.2; BD Biosciences), anti-CD57 (HCD57; BioLegend), anti-CD62L (Dreg 56; BD Biosciences), antiCD107a (H4A3; BD Biosciences), anti-perforin ( $\delta G 9$; BD Biosciences), anti-granzyme A (CB9; BD Biosciences), anti-granzyme B (Gb11; BD Biosciences), anti-granzyme K (GM6C3, Santa Cruz Biotechnology), anti-MIP-1 $\beta$ (D21-1351; BD Biosciences), anti-TNF- $\alpha$ (MAb11; BD Biosciences), and anti-IFN- $\gamma$ (4S.B3; BioLegend) were used. Fluorochromeconjugated $\operatorname{IgG}_{1}$ and $\mathrm{IgG}_{2 \mathrm{~b}}$ (MOPC-21 and 27-35; BD Biosciences) isotype control antibodies were also used. For stimulation, anti-CD16 (3G8; BD Biosciences) or anti-CD3 (S4.1; Invitrogen) were used.

\section{Flow cytometry}

For intracellular staining of perforin and other granule constituents, freshly isolated PBMCs were surface stained with fluorochrome-conjugated antibodies as indicated, as well as with a fixable dead cell stain (Live/Dead; 
Invitrogen). Cells were then fixed (Cytofix; BD Biosciences), followed by intracellular staining as indicated in permeabilization solution (Cytoperm; BD Biosciences). As controls for the internal stainings, a set of isotype control antibodies were used. For assessment of functional responses, freshly isolated PBMCs or PBMCs stimulated with IL-2 were incubated alone or with K562 cells, P815 cells, or P815 cells supplemented with either anti-CD16 or anti-CD3 antibody. After stimulation, the lymphocytes were surface stained with antibodies as indicated, as well as with a fixable dead cell stain (Live/Dead; Invitrogen). In some experiments, GolgiPlug (BD Biosciences) was added after the first hour of stimulation. Thereafter, cells were fixed, permeabilized, and stained internally with anti-MIP-1 $\beta$, anti-TNF- $\alpha$, anti-IFN- $\gamma$, and anti-CD69. All flow cytometry data were acquired on an LSR Fortessa instrument (BD Biosciences) and the resulting data were analyzed with FlowJo Version 9.4 software (TreeStar), Spice Version 5.2b software, ${ }^{31}$ and Prism Version 5.0 software (GraphPad). Probability-state modeling was performed with GemStone Version 1.0.63 software (Verity Software), and is explained in further detail in supplemental Methods and figures (available on the Blood Web site; see the Supplemental Materials link at the top of the online article).

\section{Cytotoxicity assays}

For assessment of cytotoxicity by PBMCs or isolated lymphocyte subsets, effector cells were mixed with $5 \times 10^{3}{ }^{51} \mathrm{Cr}$-labeled $\mathrm{K} 562$ cells, P815 cells, P815 cells supplemented with $0.5 \mu \mathrm{g} / \mathrm{mL}$ of anti-CD16 mAb or anti-CD3 $\mathrm{mAb}$, and incubated in triplicate for 4 hours at $37^{\circ} \mathrm{C}$. Effector-to-target cell ratios ranged from 10-0.3 in $200 \mu \mathrm{L}$ of medium in 96-well V-bottom plates. The supernatants were measured for ${ }^{51} \mathrm{Cr}$ release on a $\gamma$-counter (Cobra Gamma Counter; Packard Instruments). Cytotoxic activity in patient samples was measured as described previously. ${ }^{32}$

\section{DNA extraction, amplification, and sequence analysis}

Genomic DNA was isolated from the peripheral blood according to standard procedures. PRF1, UNC13D, STX11, and STXBP2 were sequenced as described previously. ${ }^{32}$ Primers, PCR conditions, and sequencing reaction conditions are available on request.

\section{Results}

\section{CD57 ${ }^{\text {bright }}$ expression marks perforin-expressing T-cell subsets}

To determine systematically the relationships between markers associated with lytic granule content in $\mathrm{CD}^{+} \mathrm{T}$ cells, highdimensional flow cytometric analysis coupled to multiparametric probability-state modeling was performed. ${ }^{33}$ PBMCs from healthy human adult blood donors were surface stained with fluorochromeconjugated antibodies to lineage and differentiation markers, including CD3, CD4, CD8, CD14, CD19, CD27, CD28, CD45RA, CD45RO, CD57, CD62L, and a dead cell marker. Thereafter, cells were fixed, permeabilized, and stained intracellularly with fluorochrome-conjugated antibodies to perforin and granzyme B, followed by flow cytometric analysis. Data on 30000 randomly selected $\mathrm{CD}^{+}{ }^{\mathrm{CD}} 14^{-} \mathrm{CD} 19^{-} \mathrm{CD} 4^{-} \mathrm{CD} 8^{+}$living lymphocytes $\left(\mathrm{CD}^{+}{ }^{+} \mathrm{T}\right.$ cells) from each of 12 adult donors were concatenated and subjected to probability-state modeling (Figure 1A). The parameters to be monitored were added to the model in the following order: granzyme B, perforin, CD28, CD57, CD27, and finally CD62L, which was branched because of observed heterogeneity relative to the other parameters. CD45RA and CD45RO were not included as parameters in the model because of variability relative to other markers. Intracellular perforin and granzyme B expression was closely linked and was identifiable in $25 \% \pm 13 \%$ and $27 \% \pm 14 \%$ of $\mathrm{CD}^{+} \mathrm{T}$ cells, respectively. Strikingly, the analyses revealed a strong positive correlation of intracellular perforin and granzyme B expression with surface expression of
CD57 (Figure 1A-B). In contrast, perforin and granzyme B expression were negatively correlated with $\mathrm{CD} 27$ and $\mathrm{CD} 28$ expression on $\mathrm{CD}^{+} \mathrm{T}$ cells (Figure 1A-B). According to the analysis, granzyme B was more widely expressed than CD57, whereas perforin was mostly restricted to CD57-expressing cells. Moreover, the majority of perforin- and granzyme B-expressing cells expressed CD45RA, but not CD45RO or CD62L. Probabilitystate modeling of individual healthy donors corroborated the overall phenotype of perforin- and granzyme B-expressing cells, although the size of the subsets varied from less than $5 \%$ to $35 \%$ (supplemental Figure 1). Probability-state modeling of donor 10 revealed a disparate pattern of CD57-expressing cells relative to other donors. In this donor, 44\% of CD57 cells expressed CD45RO (average $30 \% \pm 13 \%$ ) and 50\% CD45RA (average, 68\% $\pm 14 \%$ ), explaining the unique outcome of the model in this individual.

In agreement with the probability-state modeling analyses, plots of CD57 versus perforin expression in $\mathrm{CD} 8^{+} \mathrm{T}$ cells revealed that high CD57 (CD57 ${ }^{\text {bright }}$ ) expression was associated with high levels of intracellular perforin expression (Figure 1C). $\mathrm{CD}^{+} \mathrm{T}$ cells expressing low CD57 (CD57 dim) levels were mostly negative for perforin, as were $\mathrm{CD} 8^{+} \mathrm{CD} 57^{-} \mathrm{T}$ cells. Similarly, CD57 $7^{\text {bright }}$ expression was associated with intracellular perforin expression in $\mathrm{CD}^{+}$ $\mathrm{T}$ cells as well as double-negative (DN) $\mathrm{CD}^{-} \mathrm{CD}^{-} \mathrm{T}$ cells (Figure 1C). In contrast to T cells, CD57 $7^{\text {bright }}$ expression was not strictly associated with perforin expression in $\mathrm{CD} 3^{-} \mathrm{CD} 56^{\mathrm{dim}}$ NK cells, although high CD57 expression was somewhat correlated with increased expression of perforin, as described previously. ${ }^{29,34}$ $\mathrm{CD}^{-}{ }^{-} \mathrm{CD} 56^{\text {bright }} \mathrm{NK}$ cells expressed no CD57 and relatively little perforin (Figure 1C). ${ }^{23}$ Therefore, our data corroborate previous studies describing a correlation between surface CD57 and intracellular perforin and granzyme $\mathrm{B}$ expression in $\mathrm{CD}^{+} \mathrm{T}$ cells from healthy adults. ${ }^{26,29}$ In view of the data, and as Chattopadhyay et al suggested recently, ${ }^{29} \mathrm{CD} 57^{\text {bright }}$ expression may represent a useful marker of effector $\mathrm{CD} 8^{+} \mathrm{T}$ cells or bona fide CTLs, which are more commonly defined as $\mathrm{CD}^{+} \mathrm{CD} 27^{-} \mathrm{CD} 45 \mathrm{RA}^{+} \mathrm{T}^{-}$cells. ${ }^{26,27}$

In the T-cell population as a whole, CD57-expressing cells were predominately $\mathrm{CD}^{+} \mathrm{T}$ cells, but substantial populations of $\mathrm{CD} 4^{+}$ and DN CD4 ${ }^{-} \mathrm{CD}^{-}{ }^{-} \mathrm{T}$ cells also expressed CD57 in healthy adults (supplemental Figure 2). To obtain insight into the heterogeneity of CD57-expressing $\mathrm{T}$ cells and how this relates to expression of granule proteins, the phenotype of CD57-expressing T cells was examined in further detail in data concatenated from equal numbers of $\mathrm{CD}_{3}{ }^{+} \mathrm{CD} 4^{+} \mathrm{CD}^{-}, \mathrm{CD}^{+}{ }^{+} \mathrm{CD} 4^{-} \mathrm{CD}^{+}$, or $\mathrm{DN} \mathrm{CD} 3{ }^{+} \mathrm{CD} 4^{-} \mathrm{CD} 8^{-}$ cells from 7 healthy subjects (Figure 1D). CD ${ }^{+} \mathrm{CD} 57^{+} \mathrm{T}$ cells consisted primarily of $\mathrm{CD} 57^{\text {bright }} \mathrm{CD} 27^{-} \mathrm{CD} 45 \mathrm{RA}^{+}$cells and CD57 ${ }^{\mathrm{dim}} \mathrm{CD} 27^{+} \mathrm{CD} 45 \mathrm{RA}^{+/-}$cells. The former population expressed abundant levels of perforin, whereas the latter, in addition to $\mathrm{CD} 7^{-} \mathrm{CD}^{2} 7^{-} \mathrm{CD} 45 \mathrm{RA}^{+/-}$cells, expressed low levels of perforin. Among $\mathrm{CD}^{+}{ }^{+} \mathrm{T}$ cells, perforin expression was confined to a $\mathrm{CD} 7^{\text {bright }} \mathrm{CD} 27^{-}$cell subset, many of which expressed CD45RO (Figure 1D), as described previously. ${ }^{35}$ Among DN CD4 ${ }^{-} \mathrm{CD}^{-}$ $\mathrm{T}$ cells, perforin expression was similar to that of $\mathrm{CD}^{+} \mathrm{T}$ cells, being mostly confined to a $\mathrm{CD} 57^{\text {bright }} \mathrm{CD} 27^{-} \mathrm{CD} 45 \mathrm{RA}^{+}$cell subset (Figure 1D). Therefore, substantial differences exist in the differentiation stages of various perforin-expressing T-cell subsets.

\section{Comparison of granule content in cytotoxic lymphocyte subsets}

The distribution of perforin-expressing cytotoxic lymphocyte subsets, and the respective levels of perforin expressed, was assessed in healthy adults relative to CD57 expression. On average, the majority of perforin-expressing cells were either $\mathrm{CD} 8^{+} \mathrm{CD} 57^{\text {bright }} \mathrm{T}$ cells or $\mathrm{CD}^{-}{ }^{-} \mathrm{CD} 56^{\mathrm{dim}} \mathrm{NK}$ cells $(25 \% \pm 17 \%$ and $43 \% \pm 16 \%$, respectively; 
A

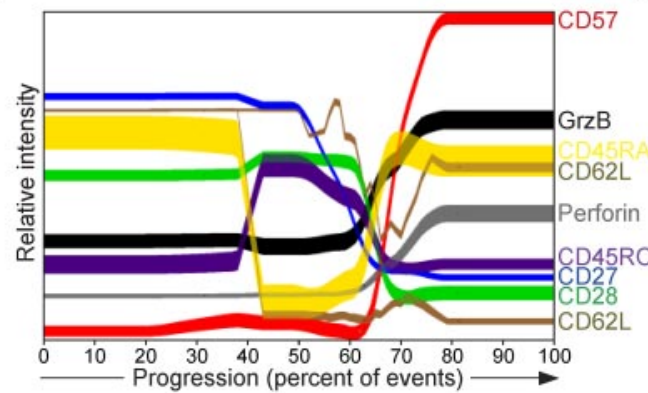

B

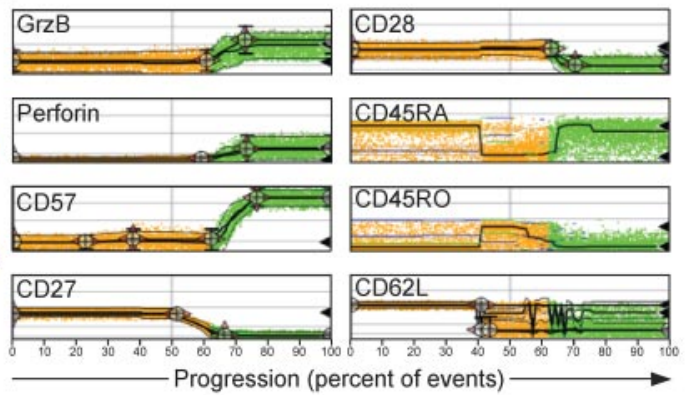

C

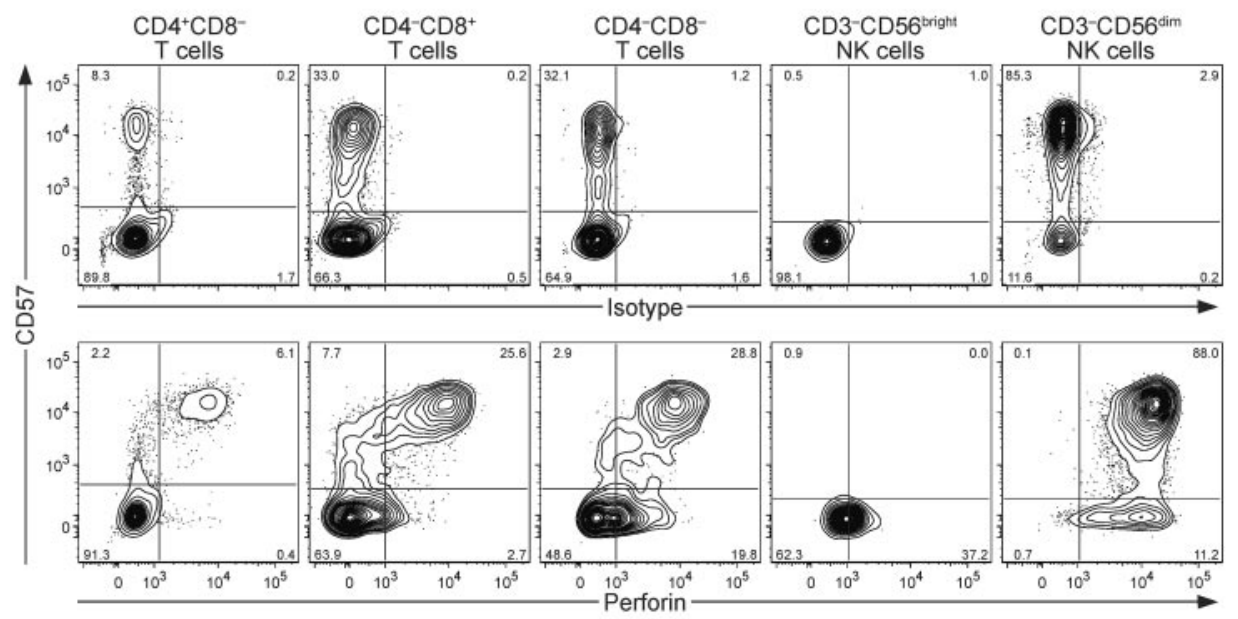

D

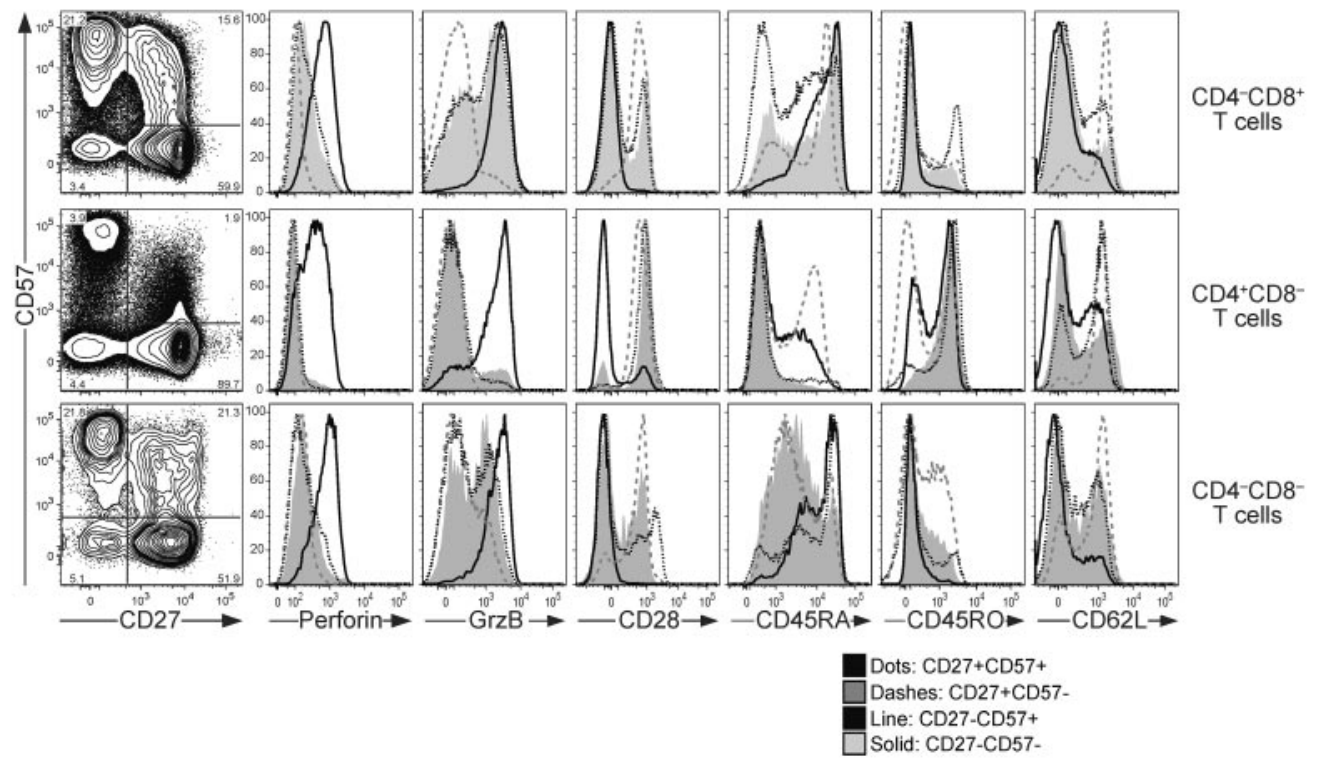

Figure 1. CD57 expression marks perforin-expressing T cells. (A-D) Freshly isolated, resting PBMCs from 12 healthy adult volunteers were surface stained with fluorochrome-conjugated antibodies to CD3, CD4, CD8, CD14, CD19, CD27, CD28, CD45RA, CD45RO, CD56, CD57, and CD62L, followed by fixation, permeabilization, and intracellular staining with isotype control antibodies or antibodies to perforin and granzyme B, and then analyzed by flow cytometry. Lymphocytes were gated on forward scatter/side scatter plots. (A-B) Concatenated data for 30000 randomly selected $\mathrm{CD} 3^{+} \mathrm{CD} 14^{-} \mathrm{CD} 19^{-} \mathrm{CD} 4^{-} \mathrm{CD} 8^{+}$living lymphocytes (CD8 ${ }^{+} \mathrm{T}$ cells) from each of 12 healthy adult donors. (A) Probability state model of CD8 ${ }^{+} \mathrm{T}$ cells. The parameters were added to the model in the following order: granzyme B, perforin, CD28, CD57, CD27, and finally $\mathrm{CD} 62 \mathrm{~L}$, which was branched because of the observed heterogeneity relative to the other parameters. CD45RA and CD45RO were not included as parameters in the model, but are displayed in the final analysis. (B) Plots showing the distribution of differentiation marker expression on individual cells, as indicated, according to the probability state model. (C) Plots show CD57 versus isotype or perforin-staining on T-cell and NK cell subsets, as indicated, from one representative donor. (D) Plots show CD57 versus CD27 staining on T-cell subsets, as indicated, on data concatenated from 7 healthy donors. Histograms display the expression of perforin, granzyme B, CD28, CD45RA, CD45RO, and $\mathrm{CD} 62 \mathrm{~L}$ in the $\mathrm{CD} 27^{+} \mathrm{CD} 57^{+}, \mathrm{CD} 27^{+} \mathrm{CD} 57^{-}, \mathrm{CD} 27^{-} \mathrm{CD} 57^{+}, \mathrm{CD} 27^{-} \mathrm{CD} 57^{-}$-cell subsets, as indicated.

mean $\pm \mathrm{SD} ; \mathrm{n}=12$; Figure $2 \mathrm{~A}) . \mathrm{DN} \mathrm{CD} 4^{-} \mathrm{CD} 8^{-} \mathrm{CD} 57^{\text {bright }}$ T cells constituted the second major population of perforin-expressing $\mathrm{T}$ cells $(8 \% \pm 6 \%) . \mathrm{CD}^{+}{ }^{+} \mathrm{CD} 57^{\text {bright }} \mathrm{T}$ cells represented only a minor subset of perforin-positive T cells $(2 \% \pm 3 \%)$. Remarkably, perforin expres- sion was significantly lower in $\mathrm{CD} 8^{+} \mathrm{CD} 57^{\text {bright }}$ and $\mathrm{DN}$ $\mathrm{CD} 4^{-} \mathrm{CD} 8^{-} \mathrm{CD} 57^{\text {bright }} \mathrm{T}$ cells compared with $\mathrm{CD} 3^{-} \mathrm{CD} 56^{\mathrm{dim}}$ NK cells (3.1 and 3.2-fold, respectively). Furthermore, perforin expression was lower in $\mathrm{CD} 4^{+} \mathrm{CD} 57^{\text {bright }} \mathrm{T}$ cells compared with 
A
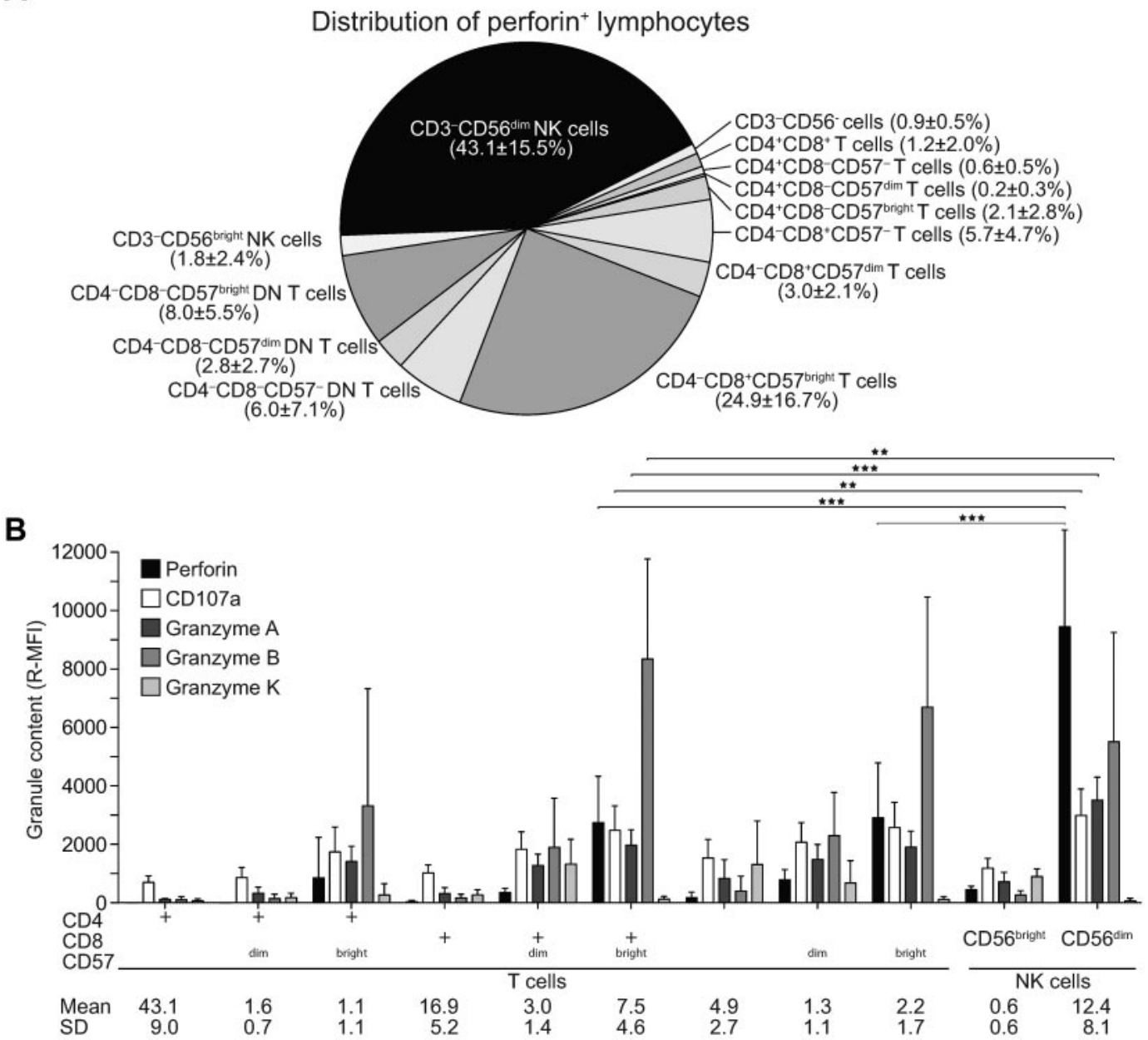

Figure 2. Quantification of perforin and other granule constituents in T-cell and NK cell subsets. (A-B) Freshly isolated, resting PBMCs from healthy adult volunteers were surface stained with fluorochrome-conjugated antibodies to CD3, CD4, CD8, CD14, CD19, CD56, and CD57, followed by fixation, permeabilization, and intracellular staining with isotype control antibodies or antibodies to perforin, CD107a, granzyme A, granzyme B, or granzyme K, and analyzed by flow cytometry. Lymphocytes were gated on forward scatter/side scatter plots. (A) Perforin-expressing cells were assessed relative to expression of the lineage markers CD3, CD4, CD8, CD56, and CD57. The pie chart depicts the relative distribution of the lymphocyte subsets, as indicated. Shading reflects the relative mean fluorescence intensity (R-MFI) of perforin staining in each subset and the frequency of each subset is indicated. Results are derived from 12 donors. Numbers indicate mean \pm SD frequencies of indicated subsets relative to the total perforin-expressing lymphocyte population. (B) Values represent R-MFI, where the MFI values of indicated staining have been subtracted from MFI values of isotype control antibodies. Values represent the means \pm SD of 12 donors. Numbers indicate mean $\pm S D$ frequencies of indicated subsets relative to the total lymphocyte population. Statistical analyses were performed using the Wilcoxon signed-rank matched pairs test. ${ }^{\star} P<.05 ;{ }^{\star \star} P<.01 ;{ }^{\star \star \star} P<.001$.

$\mathrm{CD}^{-}{ }^{-} \mathrm{CD} 56^{\mathrm{dim}} \mathrm{NK}$ cells (6.1-fold). Intracellular expression of perforin was generally very low in the CD57 ${ }^{\mathrm{dim}}$ and $\mathrm{CD} 57^{-}$T-cell subsets.

Quantification of other granule constituents, including granzyme A, granzyme B, and granzyme $\mathrm{K}$, in addition to CD107a (a marker of lysosomal membranes), by intracellular staining and flow cytometry also revealed differences. In addition to perforin, surface CD57 $7^{\text {bright }}$ expression was correlated with high intracellular expression of granzyme A and granzyme B in all T-cell subsets (Figure 2B). In contrast, granzyme $\mathrm{K}$ was not correlated with CD57 $7^{\text {bright }}$ expression (Figure 2B). Similar to perforin, granzyme A expression was lower in $\mathrm{CD} 8{ }^{+} \mathrm{CD} 57^{\text {bright }} \mathrm{T}$ cells compared with in $\mathrm{CD}^{-}{ }^{-} \mathrm{CD} 56^{\mathrm{dim}} \mathrm{NK}$ cells $(1.8$-fold). In contrast, granzyme $\mathrm{B}$ expression was higher in $\mathrm{CD} 8^{+} \mathrm{CD} 57^{\text {bright }} \mathrm{T}$ cells compared with $\mathrm{CD}^{-}{ }^{-} \mathrm{CD} 56^{\mathrm{dim}} \mathrm{NK}$ cells (1.5-fold). Granzyme $\mathrm{K}$ displayed a distinct expression pattern, with the highest expression in CD8 ${ }^{+}$CD57 ${ }^{\text {dim }} \mathrm{T}$ cells, DN $\mathrm{CD} 4^{-} \mathrm{CD} 8^{-} \mathrm{CD} 57^{-/ \text {dim }} \mathrm{T}$ cells, and $\mathrm{CD}^{-}{ }^{-} \mathrm{CD} 56^{\text {bright }} \mathrm{NK}$ cells. Intracellular CD107a expression followed the expression of cytotoxic granule constituents. In summary, although $\mathrm{CD} 8^{+} \mathrm{CD} 57^{\text {bright }} \mathrm{T}$ cells and $\mathrm{CD} 3^{-} \mathrm{CD} 56^{\mathrm{dim}} \mathrm{NK}$ cells both express abundant perforin, the composition of other granule constituents varies among the cytotoxic lymphocyte subsets.

\section{Comparison of degranulative and cytotoxic capacity of cytotoxic lymphocyte subsets}

Having established CD57 $7^{\text {bright }}$ as a useful marker of T-cell subsets with high lytic granule content, we next compared the degranulation capacity of the different T-cell and NK cell subsets. PBMCs were incubated alone or with different target cells for 2 hours at $37^{\circ} \mathrm{C}$. Thereafter, cells were stained with fluorochrome-conjugated antibodies to lineage and differentiation markers, extracellular CD107a, and a dead cell marker and analyzed by flow cytometry. All examined T-cell subsets degranulated in response to P815 target cells with anti-CD3, but not to P815 cells alone, P815 cells with anti-CD16, or K562 cells (Figure $3 \mathrm{~A}-\mathrm{B}$ ). The $\mathrm{CD} 8^{+} \mathrm{CD} 57^{\text {bright }}$ T-cell subset displayed the highest frequency of degranulation $(57 \% \pm 11 \% ; \mathrm{n}=14 ;$ Figure 3B), closely followed by $\mathrm{CD} 8{ }^{+} \mathrm{CD} 57^{\mathrm{dim}} \mathrm{T}$ cells $(52 \% \pm 12 \%)$. By comparison, $\mathrm{CD}^{+}$and $\mathrm{DN} \mathrm{CD}^{-} \mathrm{CD}^{-}$T-cell subsets degranulated less than the 


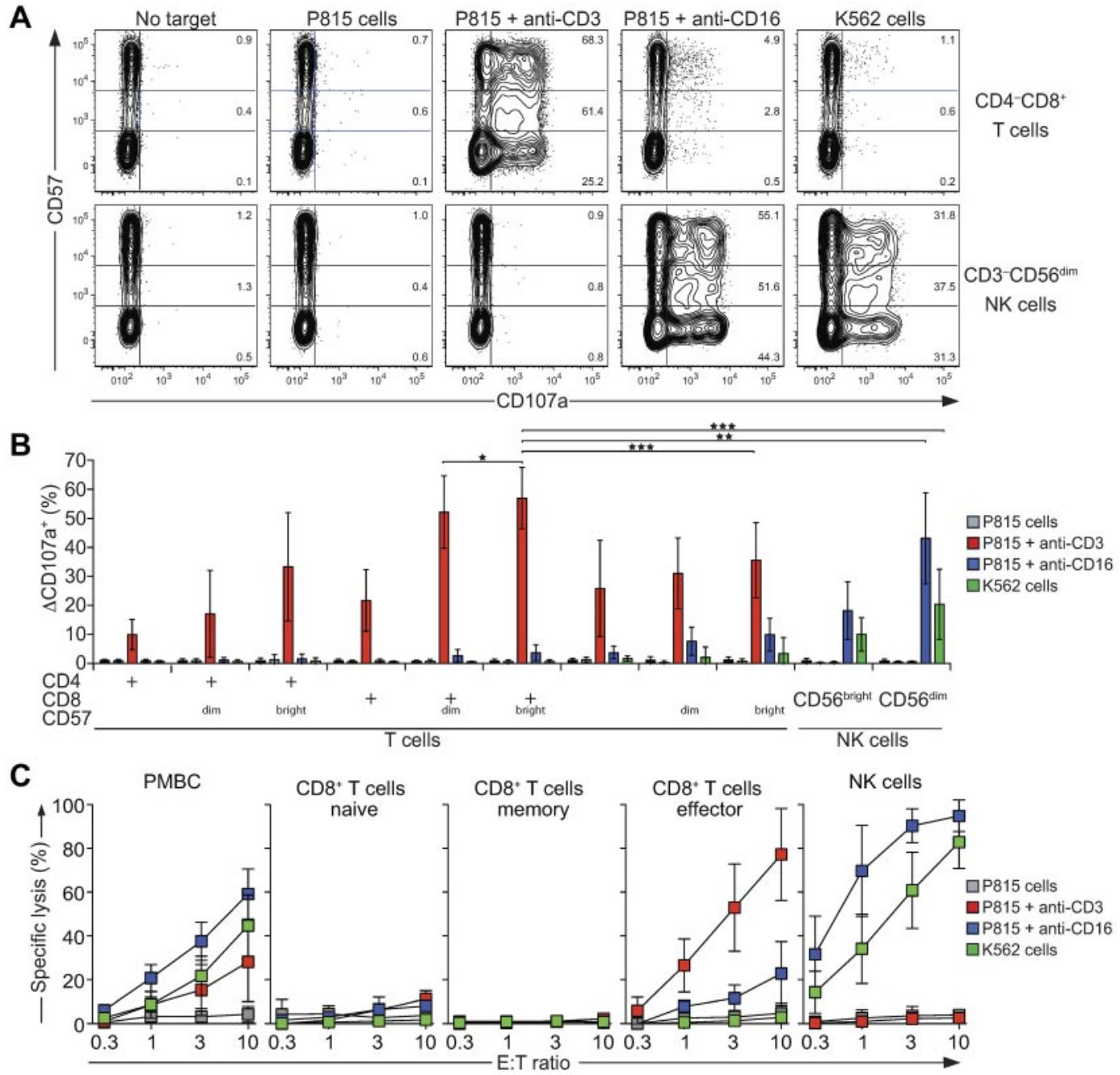

Figure 3. Degranulation and cytotoxicity by T-cell and NK cell subsets. (A-B) Freshly isolated, resting PBMCs from healthy adult volunteers were incubated alone or mixed with target cells and $\mathrm{mAbs}$, as indicated, at $37^{\circ} \mathrm{C}$ for 2 hours. Thereafter, cells were surface stained with fluorochrome-conjugated antibodies to $\mathrm{CD} 3, \mathrm{CD} 4, \mathrm{CD} 8, \mathrm{CD} 56, \mathrm{CD} 57$, and CD107a. (A) Contour plots of CD57 versus CD107a staining on CD8 ${ }^{+}$T-cell and CD3 ${ }^{-}$CD56 $^{+}$NK cell subsets after the indicated target cell stimulations. Plots with concatenated data from 6 representative donors are shown. Numbers indicate the percentages of degranulating CD57- ${ }^{-}$CD57dim, and CD57bright cells. (B) Induced CD107a surface $\left(\triangle \mathrm{CD} 107 \mathrm{a}^{+}\right)$expression on T-cell and NK cell subsets after 2 hours of target cell stimulations, as indicated. Values represent the means $\pm \mathrm{SD}$ of 14 donors. (C) $\mathrm{CD}^{+}{ }^{+} \mathrm{CD} 8^{+} \mathrm{T}$-cell subsets, as specified, or $\mathrm{CD} 3^{-} \mathrm{CD} 56^{+} \mathrm{NK}$ cells were isolated by negative selection. Effector cells were then incubated with target cells, as indicated, for 4 hours. Specific lysis was calculated. Values represent the means \pm SD of at least 4 donors. Statistical analyses were performed using the Wilcoxon signed-rank matched pairs test. ${ }^{\star} P<.05 ;{ }^{\star \star} P<.01 ;{ }^{\star \star \star} P<.001$.

$\mathrm{CD} 8{ }^{+} \mathrm{CD} 57^{+} \mathrm{T}$-cell subset, but in these subsets degranulation was also the most prominent in CD57 bright $\mathrm{T}$ cells. In contrast to $\mathrm{T}$ cells, $\mathrm{CD}^{-}{ }^{-} \mathrm{CD} 56^{\mathrm{dim}} \mathrm{NK}$ cells responded vigorously to $\mathrm{P} 815$ cells with anti-CD16 as well as to K562 cells (42\% $\pm 15 \%$ and $20 \% \pm 11 \%$, respectively; $\mathrm{n}=14$ ), but not to P815 cells alone or P815 cells with anti-CD3, as expected. ${ }^{19}$ Degranulation by $\mathrm{CD} 3{ }^{-} \mathrm{CD} 56^{\text {bright }} \mathrm{NK}$ cells was considerably lower. In summary, all T-cell subsets degranulated in response to TCR engagement. $\mathrm{CD} 8{ }^{+} \mathrm{CD} 57^{\text {bright }}$ and $\mathrm{CD} 8{ }^{+} \mathrm{CD} 57^{\mathrm{dim}} \mathrm{T}$ cells degranulated with higher frequency and with greater intensity than other T-cell subsets. Their degranulation was comparable to that of $\mathrm{CD} 3^{-} \mathrm{CD} 56^{\mathrm{dim}} \mathrm{NK}$ cells triggered by $\mathrm{CD} 16$ engagement. Therefore, the $\mathrm{CD} 8{ }^{+} \mathrm{CD} 57^{+} \mathrm{T}$-cell subset can be assessed for sensitive evaluation of the capacity for $\mathrm{CD}^{+} \mathrm{T}$ cells to degranulate.

In regard to cellular cytotoxicity, purified naive (CD45RO and CD57-depleted), memory (CD45RA and CD57-depleted), and effector (CD28 and CD45RO-depleted) T-cell subsets were isolated and mixed with different ${ }^{51} \mathrm{Cr}$-labeled target cells. Cytotoxicity by T-cell subsets was compared with that of total PBMCs and purified NK cells. Specific lysis was calculated after 4 hours of incubation. Whereas PBMCs populations lysed P815 cells in the presence of anti-CD3 or anti-CD16, as well as K562 cells, naive and memory T cells did not lyse any of the target cells (Figure 3C). In contrast, effector $\mathrm{T}$ cells efficiently lysed P815 cells with anti-CD3 and also demonstrated some lysis of P815 cells with anti-CD16, but no lysis of K562 cells (Figure 3C). Lysis of P815 cells with anti-CD3 by effector $\mathrm{T}$ cells that were more than $74 \% \pm 14 \% \mathrm{CD}^{+} \mathrm{CD}^{2} 7^{+} \mathrm{T}$ cells was at least 20 -fold more efficient than that of naive T cells. As expected, NK cells efficiently lysed P815 cells with anti-CD16 and K562 cells, but did not lyse P815 cells alone or with anti-CD3 (Figure 3C). In summary, the naive and memory CD8 T-cell subsets did not lyse P815 cells on antigen receptor engagement, whereas effector $\mathrm{CD}^{+} \mathrm{T}$ cells triggered by TCR engagement and NK cells triggered by Fc receptor engagement lysed P815 target cells to a similar extent. Therefore, the results formally demonstrate that $\mathrm{CD} 8{ }^{+} \mathrm{CD} 57^{+}$ $\mathrm{T}$ cells enriched for perforin and with high degranulative ability exhibit strong cytotoxic capacity similar to that of NK cells. 


\section{Defective degranulation by Munc13-4-, syntaxin-11-, and Munc18-2-deficient cytotoxic T cells}

To obtain insights into the degree to which CTLs and NK cells share requirements for lytic granule exocytosis and to evaluate the potential use of assays quantifying $\mathrm{CD} 8^{+} \mathrm{T}$-cell degranulation for the diagnosis of FHL patients, PBMCs from healthy donors and from patients with confirmed biallelic mutations in genes associated with FHL (supplemental Table 1) were incubated alone or with different target cells for 2 hours at $37^{\circ} \mathrm{C}$. Thereafter, the PBMCs were stained with fluorochrome-conjugated antibodies to lineage and differentiation markers, CD107a, and a dead cell marker and analyzed by flow cytometry. Whereas $\mathrm{CD}^{+} \mathrm{CD} 57^{+} \mathrm{T}$ cells from healthy controls and FHL2 patients with perforin deficiency degranulated in response to P815 target cells with anti-CD3, cells from FHL3, FHL4, and FHL5 patients did not (Figure 4A-B). In the FHL2 patients, as in healthy controls, $\mathrm{CD} 8{ }^{+} \mathrm{CD} 57^{+} \mathrm{T}$ cells degranulated more than $\mathrm{CD}^{+} \mathrm{CD}^{+} 7^{-} \mathrm{T}$ cells (Figure 4A). Relative to healthy controls, cytotoxic lymphocytes from 2 FHL2 patients displayed somewhat low degranulation, as was observed previously in NK cells from a larger cohort of FHL2 patients (Figure 4B). ${ }^{22}$ Comparison of $\mathrm{CD} 8{ }^{+} \mathrm{CD} 57^{+} \mathrm{T}$-cell and $\mathrm{CD} 3{ }^{-} \mathrm{CD} 56^{\text {dim }} \mathrm{NK}$ cell degranulation ex vivo and after IL-2 stimulation revealed similar degrees of impairment in individual FHL3, FHL4, and FHL5 patients carrying mutations in the genes encoding for Munc13-4, syntaxin-11, and Munc18-2, respectively (Figure 4B-C). Generally, T cells and NK cells from patients with $U N C 13 D, S T X 11$, or STXBP2 mutations associated with late-onset HLH both displayed somewhat more degranulation than those cells from patients with early-onset HLH. Patient FHL3-D:1 represented an exception to this. If anything, a little more degranulation was observed in resting CTLs compared with NK cells from these patients. In summary, CTLs from Munc13-4-, syntaxin-11-, and Munc18-2-deficient patients display defective degranulation. Therefore, evaluation of $\mathrm{CD} 8{ }^{+} \mathrm{CD} 57^{+} \mathrm{T}$-cell degranulation may replace analysis of NK cells in patients with too few NK cells in the circulation (eg, caused by specific defects in NK cell development or through consumption by ongoing infections) and may also complement analyses of NK cell degranulation for the diagnosis of novel primary immunodeficiency syndromes differentially affecting lymphocyte cytotoxicity.

Although almost no perforin or CD57 expression is detectable in T cells at birth, ${ }^{19,36}$ some infant patients display high frequencies of CD57-expressing CD8 ${ }^{+} \mathrm{T}$ cells (supplemental Figure 3A). The frequencies of CD57-expressing $\mathrm{CD}^{-} \mathrm{CD}^{-} 6^{+} \mathrm{NK}$ cells were low in infants, but generally higher than the frequencies of CD57expressing $\mathrm{CD}^{+} \mathrm{T}$ cells (supplemental Figure 3B-D). Only 1 of 20 patients studied was excluded because of our inability to detect sufficient $\mathrm{CD} 8{ }^{+} \mathrm{CD} 57^{+} \mathrm{T}$ cells for the assessment of T-cell degranulation. As shown in Figure 5A, analysis of patient FHL5-M:1 with a Munc18-2 deficiency, whose sample was obtained before administration of immunosuppressive treatment, also expressed a high perforin level in $\mathrm{CD}^{+} \mathrm{CD}^{-} 7^{-} \mathrm{T}$ cells (Figure 5A). Remarkably, these cells had the phenotype of $\mathrm{CD} 8^{+} \mathrm{CD} 27^{+} \mathrm{CD} 28^{+}$ $\mathrm{CD}^{2} 5 \mathrm{RA}^{-} \mathrm{CD} 45 \mathrm{RO}^{+} \mathrm{CD} 57^{-}$memory $\mathrm{T}$ cells (Figure $5 \mathrm{~B}$ ). Therefore, a subset of $\mathrm{CD} 8{ }^{+} \mathrm{CD} 57^{+} \mathrm{T}$ cells is detected in most infant FHL patients and surface CD57 expression may not be a prerequisite for perforin expression in $\mathrm{T}$ cells.

\section{Comparison of cytokine production by cytotoxic lymphocyte subsets}

Similar to NK cells, $\mathrm{CD}^{+} \mathrm{T}$ cells are important sources of proinflammatory cytokines such as TNF- $\alpha$ and IFN- $\gamma \cdot{ }^{26,37}$
$\mathrm{CD}^{-}{ }^{-} \mathrm{CD} 56^{\text {bright }} \mathrm{NK}$ cells excel at the production of cytokines after stimulation with exogenous cytokines, whereas $\mathrm{CD} 3^{-} \mathrm{CD} 56^{\mathrm{dim}}$ NK cell are better at producing cytokines on target cell recognition. ${ }^{37}$ To the best of our knowledge, cytotoxic T cells and NK cells have not been compared directly in regard to their potential for cytokine production. In a time-course experiment in the present study, PBMCs were incubated alone or with different target cells at $37^{\circ} \mathrm{C}$. Thereafter, cells were surface stained with lineage and differentiation markers, CD107a, and a dead cell marker and then fixed, permeabilized, and stained intracellularly with fluorochromeconjugated antibodies to MIP-1 $\beta$, TNF- $\alpha$, IFN- $\gamma$, and CD69, followed by flow cytometric analysis. $\mathrm{CD}^{+} \mathrm{T}$-cell subsets and $\mathrm{CD}^{-}{ }^{-} \mathrm{CD} 56^{\text {dim }} \mathrm{NK}$ cells responded rapidly to strong activation stimuli such as anti-CD3 and anti-CD16 antibodies, respectively, with expression of CD69 in more than $80 \%$ of cells. Similarly, MIP-1 $\beta$ was expressed in more than $70 \%$ of $\mathrm{CD}^{+}$T-cell subsets and $\mathrm{CD}^{-}{ }^{-} \mathrm{CD}^{2} 6^{\mathrm{dim}} \mathrm{NK}$ cells after strong activation stimuli. In contrast, $\mathrm{CD} 8^{+} \mathrm{CD} 57^{\text {bright }} \mathrm{T}$ cells produced the highest levels of TNF- $\alpha$ and IFN- $\gamma$ on stimulation compared with other $\mathrm{CD} 8^{+} \mathrm{T}$-cell subsets (Figure 6, CD8 ${ }^{+} \mathrm{CD} 57^{\text {bright }}$ vs $\mathrm{CD} 8^{+} \mathrm{CD} 57^{\text {dim }} \mathrm{T}$ cells after 2 hours of stimulation, $P<.05$ by Wilcoxon signed-rank test). Unexpectedly, by comparison, $\mathrm{CD} 8{ }^{+} \mathrm{CD} 57^{\text {bright }} \mathrm{T}$ cells responded more rapidly and vigorously in terms of MIP- $1 \beta$, TNF- $\alpha$, and IFN- $\gamma$ production to anti-CD3 antibodies than did $\mathrm{CD} 3^{-} \mathrm{CD} 56^{\mathrm{dim}}$ NK cells to anti-CD16 antibodies or coincubation with K562 cells (Figure 6; $\mathrm{CD} 8^{+} \mathrm{CD} 57^{\text {bright }} \mathrm{T}$ cells vs $\mathrm{CD} 3^{-} \mathrm{CD} 56^{\text {dim }} \mathrm{NK}$ cells after 2 hours of stimulation, $P<.05$, Wilcoxon signed-rank test). $\mathrm{CD} 8^{+} \mathrm{CD} 57^{\text {bright }} \mathrm{T}$ cells and $\mathrm{CD} 8^{+} \mathrm{CD} 57^{\mathrm{dim}} \mathrm{T}$ cells degranulated as rapidly in response to anti-CD3 antibodies as $\mathrm{CD} 3^{-} \mathrm{CD} 56^{\mathrm{dim}}$ NK cells did in response to anti-CD16 antibodies or coincubation with K562 cells (Figure 6A). Two hours of stimulation yielded many more multifunctional $\mathrm{CD} 8^{+} \mathrm{CD} 57^{\text {bright }} \mathrm{T}$ cells after TCR engagement than $\mathrm{CD}^{-}{ }^{-} \mathrm{CD} 56^{\text {dim }} \mathrm{NK}$ cells after $\mathrm{Fc}$ receptor engagement (Figure 6B). These data demonstrate that, although CTLs and NK cells have similar propensities for undergoing degranulation and for inducing CD69 and MIP-1 $\beta$ production on receptor stimulation, CTLs are better poised for the production of TNF- $\alpha$ and IFN- $\gamma$.

\section{Discussion}

The complexity of the immune system represents a challenge for understanding human immunity and implementing immunologic insights into clinical practice. ${ }^{38}$ In the present study, the probabilitystate modeling of lineage and differentiation markers on human $\mathrm{CD}^{+} \mathrm{T}$ cells revealed that $\mathrm{CD} 57^{\text {bright }}$ expression is a useful marker of perforin-containing CTLs, extending former findings by Chattopadhyay et al. ${ }^{29}$ Using CD57bright expression as a marker and comparing the granule content and function of cytotoxic lymphocyte subsets in human peripheral blood, we identified in the present study unexpected differences in granule content but similar propensities to degranulate. Moreover, cytotoxic lymphocyte degranulation was similarly impaired by a deficiency in Munc13-4, syntaxin11, or Munc18-2. CTLs excelled in cytokine production induced on target cell recognition compared with NK cells.

Methodological innovations that facilitate increasingly highdimensional flow cytometric analyses are advancing translational approaches to further understanding of the human immune system. ${ }^{39,40}$ In defined cell populations, protein concentrations in individual cells are stochastically distributed because they are subject to fluctuations due to transcriptional regulation, turnover, 
A
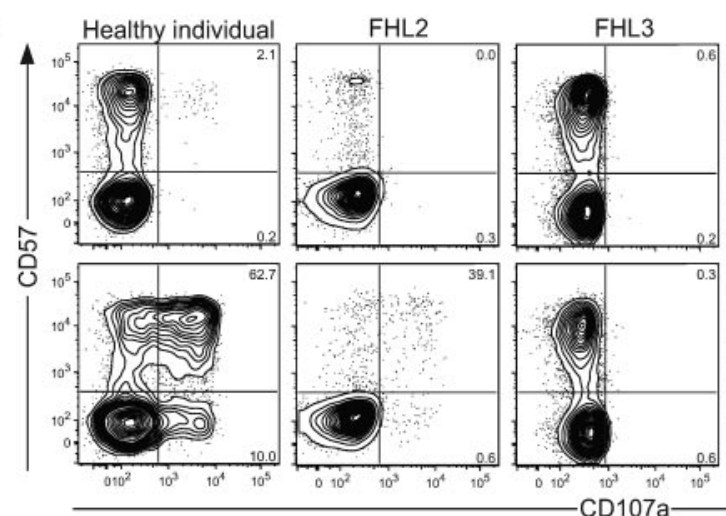

B

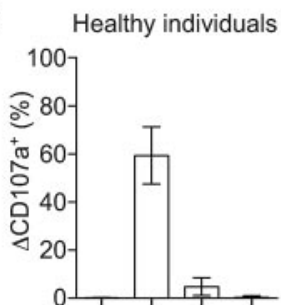

FHL2

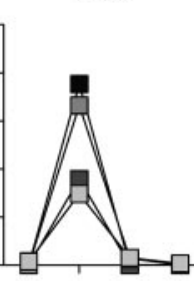

FHL3
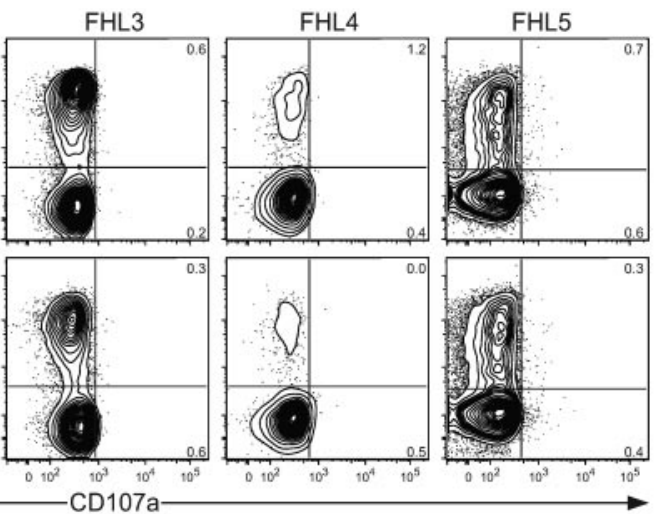

P815 cells

P815 cells

anti-CD3

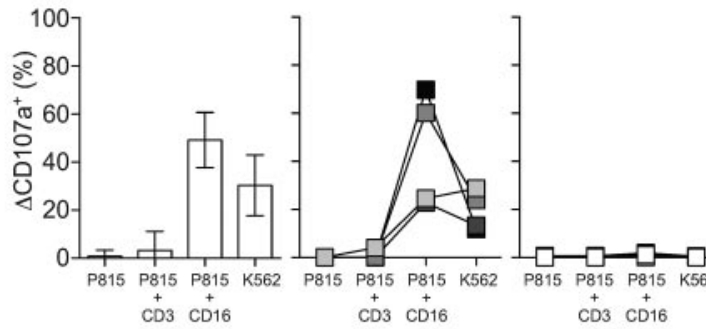

$\mathrm{FHL} 3+\mathrm{IL}-2$

$\mathrm{FHL} 4+\mathrm{IL}-2$

$\mathrm{FHL} 5+\mathrm{IL}-2$

$\mathrm{CD} 4-\mathrm{CD} 8{ }^{+} \mathrm{CD} 57^{+}$

$T$ cells

C
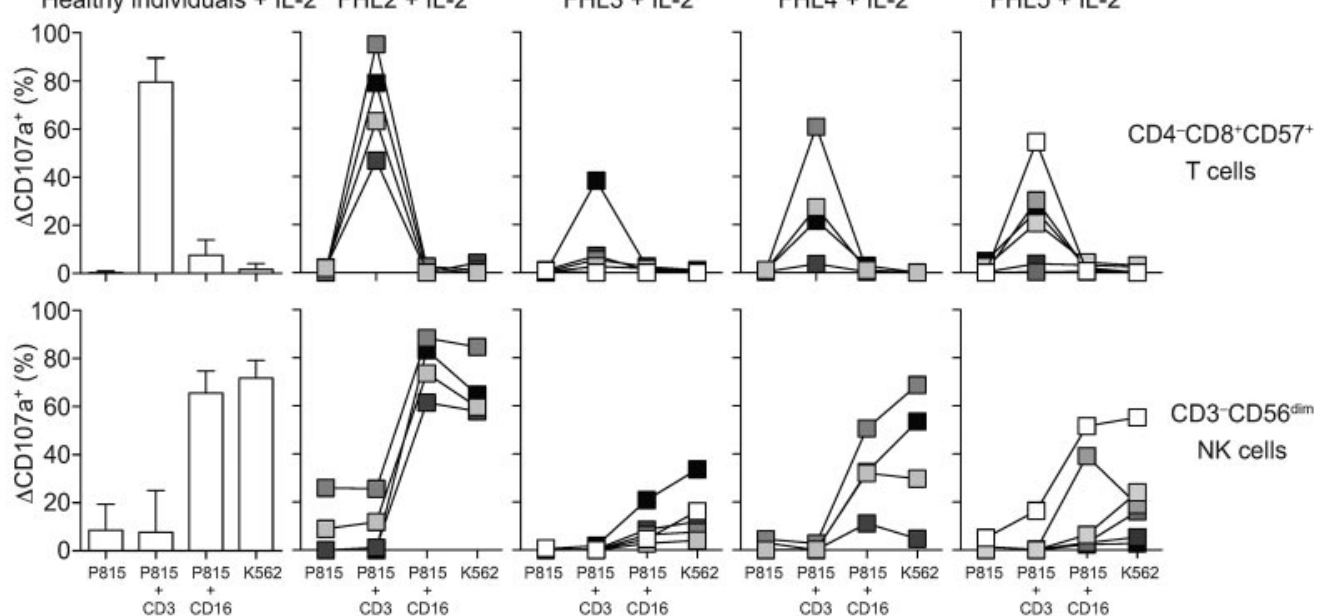

- Pat. FHL2-A:1

$\square$ Pat. FHL2-B:2

- Pat. FHL2-C:1

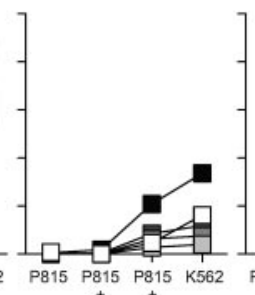

$\stackrel{+}{\mathrm{CD} 3} \mathrm{CD}^{+} 16$

Pat. FHL3-D:1

- Pat. FHL3-E:1

ㄴ. Pat. FHL3-F:1

$-\square$ Pat. FHL3-G:1

$\square$ Pat. FHL3-H:1

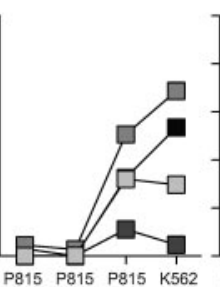

$\begin{array}{cc}+ & + \\ \mathrm{CD} 3 & \stackrel{+}{+} \mathrm{CD} 16\end{array}$

- Pat. FHL4-l:1

Pat. FHL4-J:1

- Pat. FHL4-K:

마 Pat. FHL4-L:1

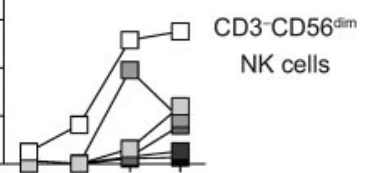

CD3-CD56

NK cells

$\mathrm{T}$ cells

$\begin{array}{lll}+ & + \\ \mathrm{CD} 3 & \mathrm{CD} 16\end{array}$

Pat. FHL5-M:1

Pat. FHL5-N:1

- Pat. FHL5-0:1

$\square$ Pat. FHL5-P:1

$\square$ Pat. FHL5-Q:1

Pat. FHL5-R:1

Figure 4. Degranulation and cytotoxicity by T-cell and NK cell subsets from patients with perforin, Munc13-4, syntaxin-11, and Munc18-2 deficiencies. (A-B) Freshly isolated, resting or (C) IL-2-stimulated PBMCs from healthy adult volunteers or patients with biallelic mutations in FHL-associated genes were incubated alone or mixed with target cells and $\mathrm{mAbs}$, as indicated, at $37^{\circ} \mathrm{C}$. Thereafter, cells were surface stained with fluorochrome-conjugated antibodies to CD3, CD4, CD8, CD56, CD57, and CD107a. (A) Contour plots of CD57 versus CD107a staining on $\mathrm{CD}^{+} \mathrm{T}$-cell subsets after 2 hours of the indicated target cell stimulations. Plots of representative donors and patients are shown. Numbers indicate percentages of degranulating CD57- and CD57 ${ }^{+}$cells. (B-C) Induced CD107a surface ( $\left.\triangle \mathrm{CD} 107 \mathrm{a}^{+}\right)$expression on freshly isolated (B) or IL-2-stimulated (C) $\mathrm{CD} 8^{+} \mathrm{CD} 57^{+} \mathrm{T}$-cell and $\mathrm{CD}^{-}{ }^{-} \mathrm{CD} 56^{+} \mathrm{NK}$ cell subsets after 2 hours of target cell stimulations, as indicated. For healthy donors, bars indicate the mean $\pm \mathrm{SD}$ of 34 donors. For patients, which are color-coded according to age at onset, boxes indicate values for each patient and are linked with lines.

and environmental perturbations. Although signal-to-noise ratios vary with time, flow cytometry captures a snapshot of such variations. When interrogating aspects of cellular populations and networks by such steady-state measurements of individual 
A

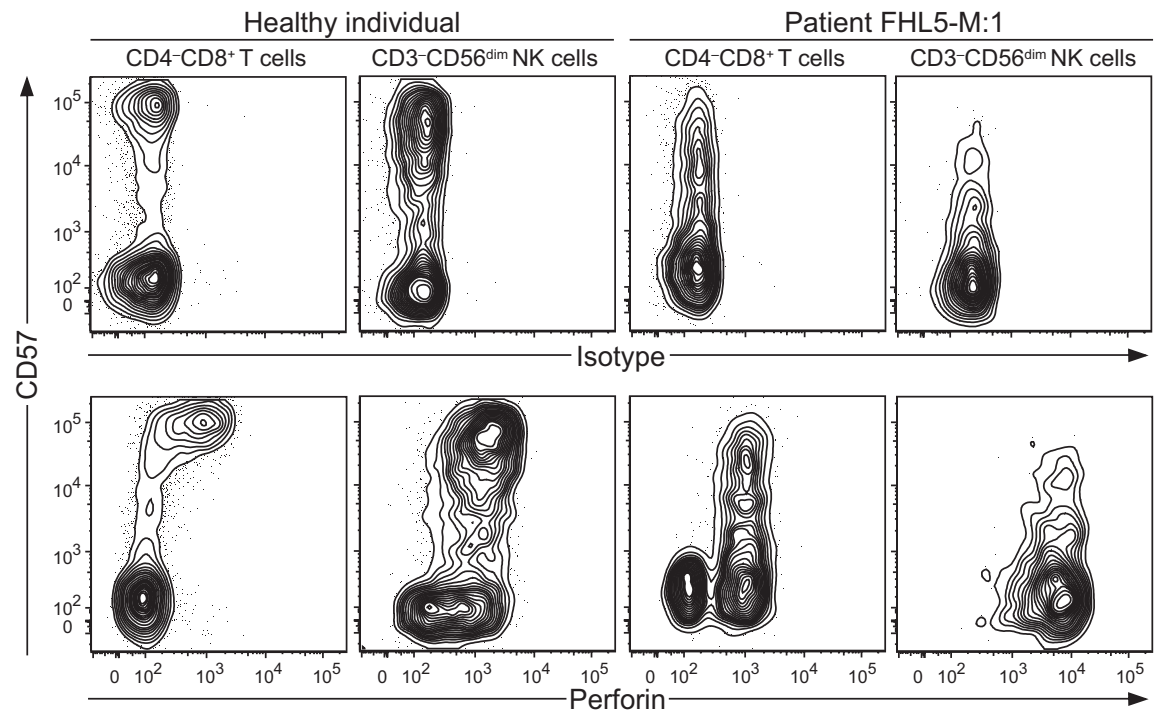

B

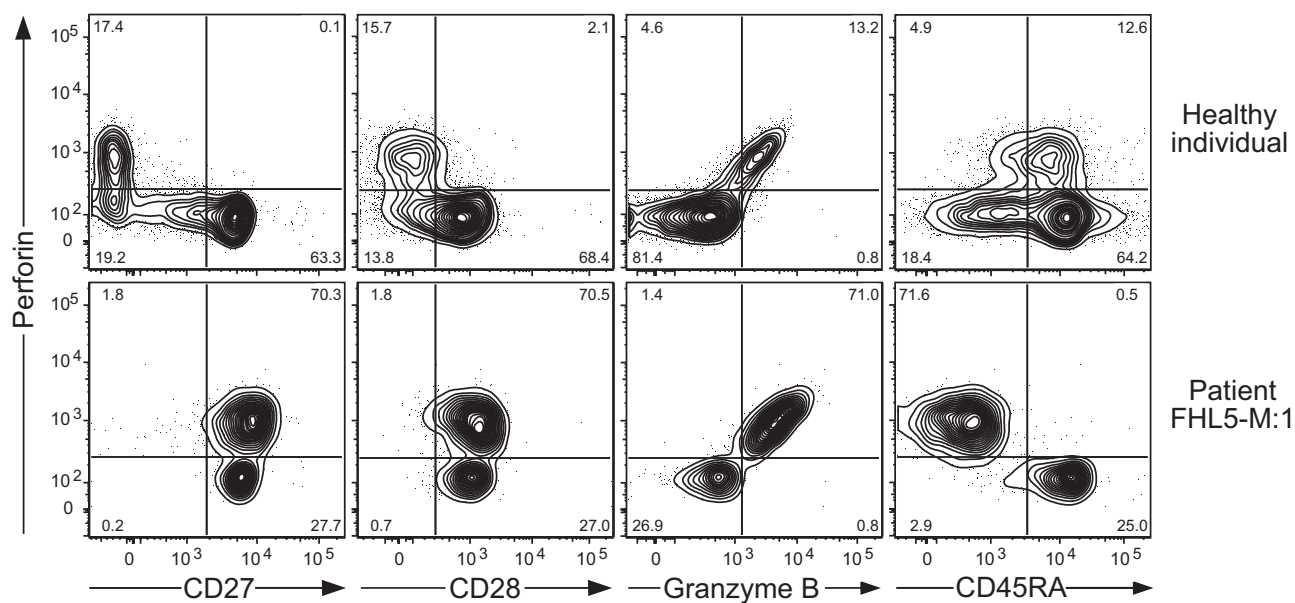

Figure 5. Perforin expression in T-cell subsets from a Munc18-2-deficient patient with ongoing HLH. Freshly isolated PBMCs from healthy adult volunteers and an untreated Munc18-2-deficient patient with HLH were surface stained with fluorochrome-conjugated antibodies to CD3, CD4, CD8, CD14, CD19, CD27, CD28, CD45RA, CD45RO, CD56, and CD57, followed by fixation, permeabilization, and intracellular staining with isotype control or anti-perforin and anti-granzyme B antibodies or antibodies to perforin and granzyme B, and then analyzed by flow cytometry. (A) Plots showing CD57 versus isotype or perforin-staining on T-cell and NK cell subsets, as indicated. (B) Plots showing CD57 versus CD27 staining on T-cell subsets, as indicated. Histograms display the expression of perforin, granzyme B, CD28, CD45RA, CD45RO, and CD62L in the $\mathrm{CD} 27^{+} \mathrm{CD} 57^{+}$and $\mathrm{CD} 27^{+} \mathrm{CD} 57^{-}$- -cell subsets, as indicated.

components, efficient methods to simulate, compute, and visualize high-dimensional distributions are needed. In the present study, we have demonstrated the efficacy of probability-state modeling on $\mathrm{CD}^{+}$T-cell differentiation, illustrating a strong correlation between perforin and CD57 expression.

In 1981, Abo and Balch first described the CD57 antigen as a differentiation antigen associated with cytotoxic activity. ${ }^{41}$ Interestingly, the expression of CD57 is almost absent in newborns, but increases with age. ${ }^{42} \mathrm{CMV}$ and other viral infections promote the development of CD57-expressing $\mathrm{T}_{\text {cells. }}{ }^{42}$ Analysis of $\mathrm{CD}^{+}$ T-cell subsets suggested a sequential acquisition of granzymes, CD57, and perforin. This was not the case for NK cells, in which perforin expression was also present in $\mathrm{CD}^{-} 7^{-}$cells. Moreover, analysis of a patient with ongoing HLH (ie, a systemic inflammatory state) suggested that perforin expression may not necessarily be coupled to CD57 in T cells. In vitro experiments indicated that perforin can be rapidly up-regulated on TCR engagement. ${ }^{43}$ Therefore, CD57 ${ }^{\text {bright }}$ expression does not appear to be a prerequisite for intracellular perforin expression, although CD57 7 bright expression generally marks perforin-expressing $\mathrm{T}$ cells. Expression of distinct granzymes is regulated on $\mathrm{CD}^{+}{ }^{+} \mathrm{T}$-cell differentiation. ${ }^{44,45}$ How TCR and cytokines signals epigenetically regulate effector molecule and CD57 expression during T-cell differentiation will be an interesting subject for future studies.

In the present study, we compared the phenotype and granule content of distinct CD57-expressing lymphocyte subsets ex vivo. These analyses revealed a variable content of cytotoxic granule constituents. In comparison, $\mathrm{CD} 3^{-} \mathrm{CD} 56^{\mathrm{dim}} \mathrm{NK}$ cells expressed more perforin and granzyme $\mathrm{A}$ than did $\mathrm{CD} 8^{+} \mathrm{CD} 57^{\text {bright }} \mathrm{T}$ cells, whereas the $\mathrm{CD} 8{ }^{+} \mathrm{CD} 57^{\text {bright }} \mathrm{T}$ cells expressed more granzyme $\mathrm{B}$. Granzyme B is a potent inducer of apoptosis through caspasedependent and -independent mechanisms. ${ }^{46}$ Granzyme A is considered a weak mediator of caspase-independent cell death. ${ }^{46}$ In addition, mounting evidence suggests a role for granzyme A in promoting inflammation through proteolysis of cytokines. ${ }^{47} \mathrm{Al}-$ though in our analyses CTLs and NK cells that were provided appropriate activation signals displayed similar capacities to kill target cells, it is tempting to speculate that the differences in their granule content might differentially affect cell death and inflammation. 


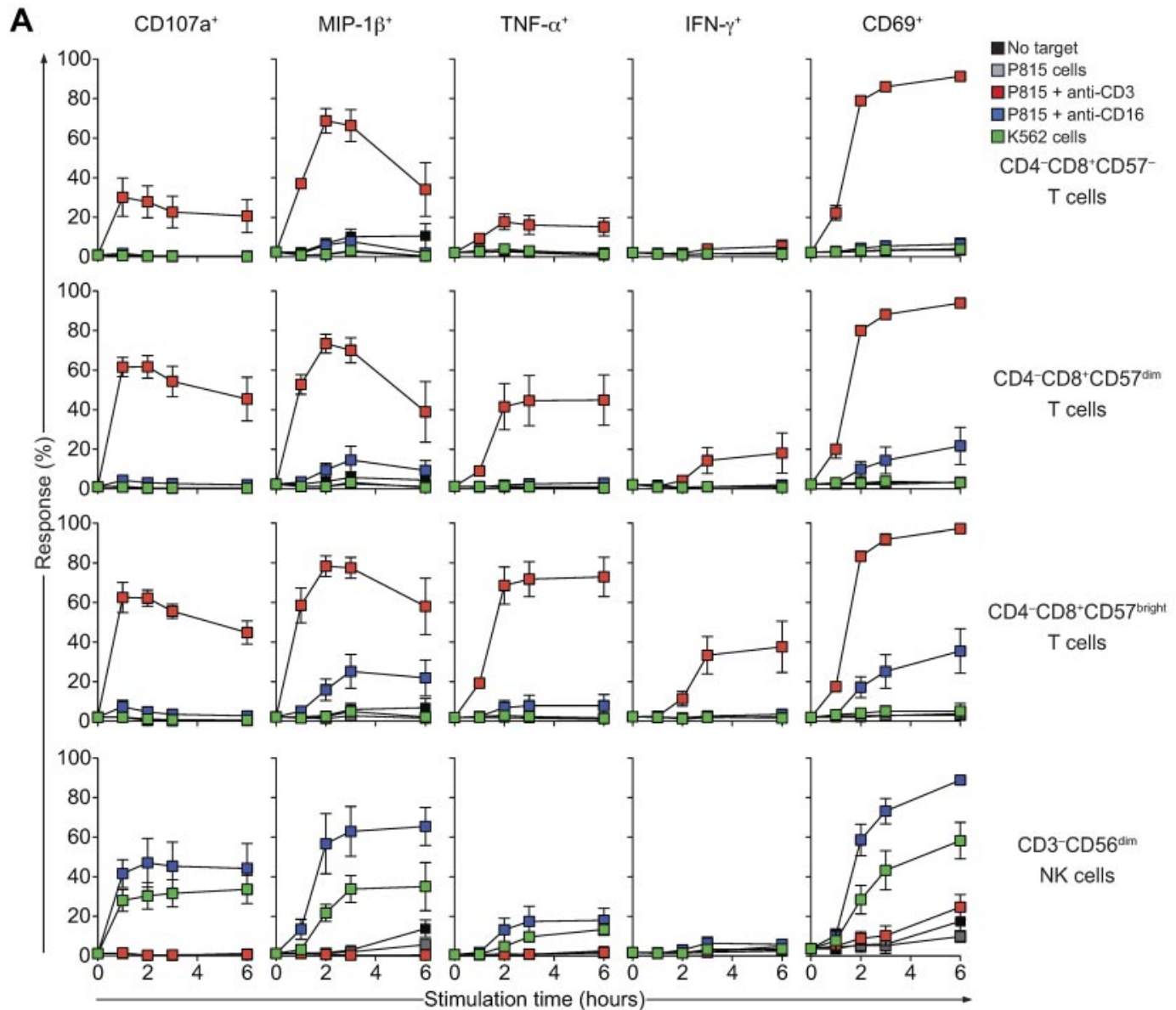

B

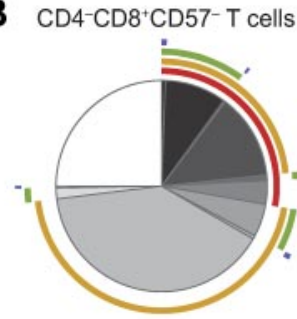

Stimulus: P815 + anti-CD3

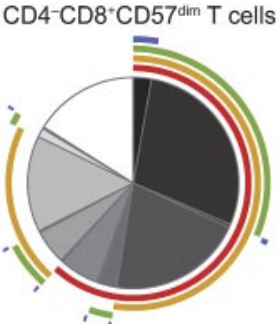

P815 + anti-CD3

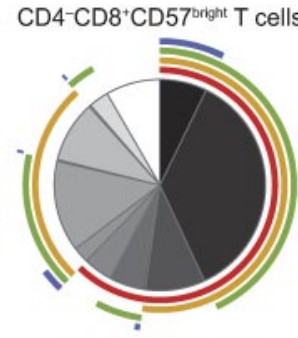

P815 + anti-CD3

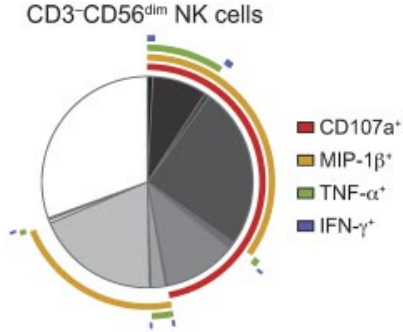

P815 + anti-CD16

Figure 6. Time-course analysis of degranulation and cytokine responses by different T-cell and NK cell subsets from healthy adults. Freshly isolated, resting PBMCs from healthy adult volunteers were incubated alone or mixed with target cells and mAbs, as indicated, at $37^{\circ} \mathrm{C}$. Thereafter, cells were surface stained with fluorochrome-conjugated antibodies to CD3, CD4, CD8, CD56, CD57, and CD107a, followed by fixation, permeabilization, and intracellular staining with antibodies to MIP-1 $\beta$, TNF- $\alpha$, IFN- $\gamma$, and CD69. (A) Time course of functional responses on CD8 ${ }^{+}$T-cell subsets and CD3 ${ }^{-} \mathrm{CD}_{56}{ }^{+} \mathrm{NK}_{\text {cells }}$ after target cell stimulations, as indicated. Values represent the means $\pm S D$ of 6 donors from 1 of 3 independent experiments. (B) Indicated lymphocyte cells were gated and a Boolean gating strategy was used for analysis. Pie charts represent the frequency of cells positive for the given number of measured responses (ie, CD107a, MIP-1 $\beta$, TNF- $\alpha$, and IFN- $\gamma$ ). Therefore, cells can be categorized into the number of responses they display. Arcs depict the relative frequency of cells specifically positive for CD107a, MIP-1 $\beta$, TNF- $\alpha$, and/or IFN- $\gamma$ staining, as indicated. Values represent the means of 6 different donors from 1 of 3 independent experiments.

NK cells are often considered to be important early mediators of immune responses in terms of cytokine production. Such cytokine production is induced by target cell engagement in $\mathrm{CD} 3^{-} \mathrm{CD} 56^{\mathrm{dim}}$ $\mathrm{NK}$ cells, whereas $\mathrm{CD} 3^{-} \mathrm{CD} 56^{\text {bright }} \mathrm{NK}$ cells respond more vigorously albeit more slowly to exogenous cytokines. ${ }^{37}$ In our experiments, $\mathrm{CD} 8^{+} \mathrm{CD} 57^{\text {bright }} \mathrm{T}$ cells produced TNF- $\alpha$ and IFN- $\gamma$ more rapidly and with greater frequency than did $\mathrm{CD} 3^{-} \mathrm{CD} 56^{\mathrm{dim}} \mathrm{NK}$ cells. These differences demonstrate a greater propensity for effector $\mathrm{T}$ cells to produce proinflammatory cytokines on activation. This ability to more rapidly respond to stimuli might reflect epigenetic differences at the cytokine gene loci during T-cell differentiation that do not occur in NK cells. Therefore, further comparisons of
T-cell and NK cell subsets in regard to epigenetic regulation of cytokine genes will be interesting.

Assays assessing NK cell degranulation provide a sensitive means for the diagnosis of FHL. ${ }^{19,21,22}$ In this setting, quantification of the frequency of cells with induced CD107a surface expression and intensity of CD107a staining is informative. ${ }^{48,49}$ In the clinical setting, sensitive and reproducible assays for the quantification of other major cytotoxic lymphocyte subsets would be useful for several reasons. First, some patients have very few circulating NK cells. Therefore, in these patients, assays quantifying degranulation in other cytotoxic lymphocyte subsets could provide a means of diagnosis. Second, quantification of degranulation in additional 
cytotoxic subsets could strengthen suspicion of defects in patients with abnormal or borderline NK cell degranulation. Third, differences in CTL and NK cell function may exist and may be clinically relevant for the diagnosis of novel primary immune deficiency disease. Assays quantifying CTL degranulation using phytohemagglutinin and IL-2-stimulated blasts have been described previously. ${ }^{22,50}$ However, these assays have been difficult to interpret because of high assay variability and donor-to-donor variation; they also require at least 48 hours of prestimulation. Gating on $\mathrm{CD} 8{ }^{+} \mathrm{CD} 57^{+} \mathrm{CTLs}$, we observed in the present study robust responses with relatively low donor-to-donor variability in freshly isolated cells. In fact, degranulative responses by $\mathrm{CD} 8^{+} \mathrm{CD} 57^{+}$ $\mathrm{T}$ cells on $\mathrm{CD} 3$ stimulation were greater in magnitude and displayed considerably less SD than those by NK cells on K562 stimulation. Therefore, assays quantifying degranulation by $\mathrm{CD} 8{ }^{+} \mathrm{CD} 57^{+} \mathrm{T}$ cells may offer a more sensitive and rapid means of detecting defects in degranulation. The use of multiple stimulations with better signal-to-noise ratios may be particularly useful for identifying patients with milder defects associated with later clinical presentations. A limitation of such assays is that differentiated, CD57-expressing T cells are absent at birth ${ }^{36}$ and develop in response to infections. However, we were able to detect and assess perforin-expressing $\mathrm{CD} 8{ }^{+} \mathrm{CD} 57^{+} \mathrm{T}$ cells from infants as young as 1 month of age. This suggests that such effector $\mathrm{CD} 8^{+} \mathrm{CD} 57^{+}$ $\mathrm{T}$ cells develop rapidly in infants, possibly driven by infections that may also act as triggers of HLH. If parameters are limited because of flow cytometry constraints, analysis of CD107a expression on $\mathrm{CD} 3{ }^{+} \mathrm{CD} 57^{+} \mathrm{T}$ cells can provide a better indication of the capacity of $\mathrm{T}$ cells to degranulate than analysis on $\mathrm{CD}^{+} \mathrm{CD}^{+} \mathrm{T}$ cells (supplemental Figure 4).

In conclusion, the results of the present study, together with those of Chattopadhyay et al, ${ }^{29}$ provide a rational to use $\mathrm{CD} 57$ bright expression as a marker of CTLs in humans and further highlights the similarities and differences in cytotoxic lymphocyte subset phenotype and function. From a primary immunodeficiency disease perspective, evaluation of CD57 $7^{\text {bright }} \mathrm{T}$-cell numbers might aid in the diagnosis of syndromes with impaired CTL development. Assays quantifying both CTL and NK cell degranulation may provide a better means for diagnosis of patients with late-onset FHL associated with more subtle defects in cytotoxic lymphocyte degranulation. Moreover, such approaches may unravel novel primary immunodeficiency diseases associated with selective defects in CTL or NK cell function. The efficacy of assays quantifying degranulation by $\mathrm{CD} 8{ }^{+} \mathrm{CD} 57^{+} \mathrm{T}$ cells for the diagnosis of defects in lymphocyte cytotoxicity will be assessed in future studies.

\section{Acknowledgments}

The authors thank the patients and their families for their participation.

This work was supported by the Swedish Research Council, Swedish Cancer Foundation, Swedish Children's Cancer Foundation, Åke Olsson Foundation for Hematologic Research, Histiocytosis Association, Tobias Foundation, Jeansson's Foundation, Åke Wiberg's Foundation, Clas Groschinsky's Memorial Fund, the Karolinska Institute Research Foundation, and the Stockholm County Council (ALF project).

\section{Authorship}

Contribution: S.C.C.C., J.T., and Y.T.B. designed the research, performed the experiments, analyzed the results, and wrote the manuscript; M.E., M. Meeths, and M. Mastafa performed the sequencing and analyzed the results; W.A.-H., P.F., K.C.G, M.I., C.L., M. Machaczka, A.N., J.P., A.P.-M., M.S., E.U., S.U., and J.W. cared for the patients and provided clinical data; and M.N., H.G.L., and J.-I.H. wrote the manuscript.

Conflict-of-interest disclosure: The authors declare no competing financial interests.

Correspondence: Yenan Bryceson, $\mathrm{PhD}$, Center for Infectious Medicine, F59, Department of Medicine, Karolinska Institutet, Karolinska University Hospital Huddinge, S-141-86 Stockholm, Sweden; e-mail: yenan.bryceson@ki.se.

\section{References}

1. Lieberman J. The ABCs of granule-mediated cy totoxicity: new weapons in the arsenal. Nat Rev Immunol. 2003;3(5):361-370.

2. Voskoboinik I, Dunstone MA, Baran K, Whisstock JC, Trapani JA. Perforin: structure, function, and role in human immunopathology. Immunol Rev. 2010; 235(1):35-54.

3. Davis MM, Krogsgaard M, Huse M, Huppa J, Lillemeier BF, Li QJ. T cells as a self-referential, sensory organ. Annu Rev Immunol. 2007;25:681695.

4. Lanier LL. Up on the tightrope: natural killer cell activation and inhibition. Nat Immunol. 2008;9(5): 495-502.

5. Bryceson YT, Chiang SC, Darmanin S, Schlums H, Theorell JT, Wood SM. Molecular mechanisms of NK cell activation. J Innate Immun. 2011;3(3):216226.

6. de Saint Basile G, Menasche G, Fischer A. Molecular mechanisms of biogenesis and exocytosis of cytotoxic granules. Nat Rev Immunol. 2010 10(8):568-579.

7. Wulfing C, Purtic B, Klem J, Schatzle JD. Stepwise cytoskeletal polarization as a series of checkpoints in innate but not adaptive cytolytic killing. Proc Natl Acad Sci U S A. 2003;100(13): 7767-7772.

8. Deguine J, Breart B, Lemaitre F, Di Santo JP,
Bousso P. Intravital imaging reveals distinct dynamics for natural killer and CD8(+) T cells during tumor regression. Immunity. 2010;33(4):632644.

9. Stepp SE, Dufourcq-Lagelouse R, Le Deist F, et al. Perforin gene defects in familial hemophagocytic lymphohistiocytosis. Science. 1999;286(5446):19571959.

10. Janka GE. Hemophagocytic syndromes. Blood Rev. 2007;21(5):245-253.

11. Filipovich $\mathrm{AH}$. Hemophagocytic lymphohistiocytosis and related disorders. Curr Opin Allergy Clin Immunol. 2006;6(6):410-415.

12. Gupta S, Weitzman S. Primary and secondary hemophagocytic lymphohistiocytosis: clinical features, pathogenesis and therapy. Expert Rev Clin Immunol. 2010;6(1):137-154.

13. Clementi R, Locatelli F, Dupre L, et al. A proportion of patients with lymphoma may harbor mutations of the perforin gene. Blood. 2005;105(11): 4424-4428.

14. Chia J, Yeo KP, Whisstock JC, Dunstone MA Trapani JA, Voskoboinik I. Temperature sensitivity of human perforin mutants unmasks subtotal loss of cytotoxicity, delayed FHL, and a predisposition to cancer. Proc Natl Acad Sci U S A. 2009; 106(24):9809-9814.

15. Feldmann J, Callebaut I, Raposo G, et al.
Munc13-4 is essential for cytolytic granules fusion and is mutated in a form of familial hemophagocytic lymphohistiocytosis (FHL3). Cell. 2003, 115(4):461-473.

16. zur Stadt U, Schmidt S, Kasper B, et al. Linkage of familial hemophagocytic lymphohistiocytosis (FHL) type-4 to chromosome 6q24 and identification of mutations in syntaxin 11. Hum Mol Genet. 2005;14(6):827-834

17. zur Stadt U, Rohr J, Seifert W, et al. Familial hemophagocytic lymphohistiocytosis type 5 (FHL-5) is caused by mutations in Munc18-2 and impaired binding to syntaxin 11. Am J Hum Genet. 2009; 85(4):482-492.

18. Cote M, Menager MM, Burgess A, et al. Munc18-2 deficiency causes familial hemophagocytic lymphohistiocytosis type 5 and impairs cytotoxic granule exocytosis in patient NK cells. J Clin Invest. 2009;119(12):3765-3773.

19. Bryceson YT, Rudd E, Zheng C, et al. Defective cytotoxic lymphocyte degranulation in syntaxin-11 deficient familial hemophagocytic lymphohistiocytosis 4 (FHL4) patients. Blood. 2007;110(6):19061915.

20. Henter JI, Horne A, Arico M, et al. HLH-2004: Diagnostic and therapeutic guidelines for hemophagocytic lymphohistiocytosis. Pediatr Blood Cancer. 2007;48(2):124-131. 
21. Marcenaro S, Gallo F, Martini S, et al. Analysis of natural killer-cell function in familial hemophagocytic lymphohistiocytosis (FHL): defective CD107a surface expression heralds Munc13-4 defect and discriminates between genetic subtypes of the disease. Blood. 2006;108(7):23162323.

22. Bryceson YT, Pende D, Maul-Pavicic A et al. A prospective evaluation of degranulation assays in the rapid diagnosis of familial hemophagocytic syndromes. Blood. 2012;119(12):2754-2763.

23. Caligiuri MA. Human natural killer cells. Blood. 2008;112(3):461-469.

24. Parish IA, Kaech SM. Diversity in CD8(+) T cell differentiation. Curr Opin Immunol. 2009;21(3): 291-297.

25. Zhang N, Bevan MJ. CD8(+) T cells: foot soldiers of the immune system. Immunity. 2011;35(2):161. 168.

26. Hamann D, Baars PA, Rep MH, et al. Phenotypic and functional separation of memory and effector human CD8 + T cells. J Exp Med. 1997;186(9): 1407-1418.

27. van Lier RA, ten Berge IJ, Gamadia LE. Human CD8(+) T-cell differentiation in response to viruses. Nat Rev Immunol. 2003;3(12):931-939.

28. Pittet MJ, Speiser DE, Valmori D, Cerottini JC, Romero P. Cutting edge: cytolytic effector function in human circulating CD8 + T cells closely correlates with CD56 surface expression. J Immunol. 2000;164(3):1148-1152.

29. Chattopadhyay PK, Betts MR, Price DA, et al. The cytolytic enzymes granyzme A, granzyme B, and perforin: expression patterns, cell distribution, and their relationship to cell maturity and bright CD57 expression. J Leukoc Biol. 2009; 85(1):88-97.

30. Appay V, van Lier RA, Sallusto F, Roederer M. Phenotype and function of human $T$ lymphocyte subsets: consensus and issues. Cytometry $A$. 2008;73(11):975-983.

31. Roederer M, Nozzi JL, Nason MC. SPICE: explo- ration and analysis of post-cytometric complex multivariate datasets. Cytometry A. 2011;79(2): 167-174

32. Meeths M, Chiang SC, Wood SM, et al. Familial hemophagocytic lymphohistiocytosis type 3 (FHL3) caused by deep intronic mutation and inversion in UNC13D. Blood. 2011;118(22):57835793.

33. Bagwell BC. Breaking the Dimensionality Barrier. In: Hawley TS, Hawley RG, eds. Flow Cytometry Protocols, Methods in Molecular Biology. Vol 699. Berlin, Germany: Springer; 2011:31-51.

34. Bjorkstrom NK, Riese P, Heuts F, et al. Expression patterns of NKG2A, KIR, and CD57 define a process of CD56dim NK-cell differentiation uncoupled from NK-cell education. Blood. 2010; 116(19):3853-3864

35. van de Berg PJ, van Leeuwen EM, ten Berge IJ, van Lier R. Cytotoxic human CD4(+) T cells. Curr Opin Immunol. 2008;20(3):339-343.

36. Berthou C, Legros-Maida S, Soulie A, et al. Cord blood T lymphocytes lack constitutive perforin expression in contrast to adult peripheral blood T lymphocytes. Blood. 1995;85(6):1540-1546.

37. Fauriat $\mathrm{C}$, Long $\mathrm{EO}$, Ljunggren $\mathrm{HG}$, Bryceson $\mathrm{YT}$. Regulation of human NK cell cytokine and chemokine production by target cell recognition. Blood. 2010;115(6):2167-2176.

38. Davis MM. A prescription for human immunology. Immunity. 2008;29(6):835-838.

39. Biancotto A, Fuchs JC, Williams A, Dagur PK McCoy JP Jr. High dimensional flow cytometry for comprehensive leukocyte immunophenotyping (CLIP) in translational research. J Immunol Methods. 2011;363(2):245-261.

40. Newell EW, Sigal N, Bendall SC, Nolan GP, Davis MM. Cytometry by time-of-flight shows combinatorial cytokine expression and virusspecific cell niches within a continuum of CD8+ T cell phenotypes. Immunity. 2012;36(1):142-152.

41. Abo T, Balch CM. A differentiation antigen of hu man NK and $\mathrm{K}$ cells identified by a monoclonal antibody (HNK-1). J Immunol. 1981;127(3):10241029.

42. Focosi D, Bestagno M, Burrone O, Petrini M CD57+ T lymphocytes and functional immune deficiency. J Leukoc Biol. 2010;87(1):107-116.

43. Makedonas G, Banerjee PP, Pandey R, et al. Rapid up-regulation and granule-independent transport of perforin to the immunological synapse define a novel mechanism of antigenspecific CD8 + T cell cytotoxic activity. J Immunol. 2009;182(9):5560-5569.

44. Bratke K, Kuepper M, Bade B, Virchow JC Jr, Luttmann W. Differential expression of human granzymes A, B, and $\mathrm{K}$ in natural killer cells and during CD8 $+\mathrm{T}$ cell differentiation in peripheral blood. Eur J Immunol. 2005;35(9):2608-2616.

45. Takata H, Takiguchi M. Three memory subsets of human CD8 + T cells differently expressing three cytolytic effector molecules. J Immunol. 2006; 177(7):4330-4340.

46. Anthony DA, Andrews DM, Watt SV, Trapani JA, Smyth MJ. Functional dissection of the granzyme family: cell death and inflammation. Immunol Rev. 2010;235(1):73-92.

47. Froelich CJ, Pardo J, Simon MM. Granuleassociated serine proteases: granzymes might not just be killer proteases. Trends Immunol. 2009;30(3):117-123.

48. Rudd E, Bryceson YT, Zheng C, et al. Spectrum, and clinical and functional implications of UNC13D mutations in familial hemophagocytic lymphohistiocytosis. J Med Genet. 2008;45(3): 134-141.

49. Macartney CA, Weitzman S, Wood SM, et al. Unusual functional manifestations of a novel STX11 frameshift mutation in two infants with familial hemophagocytic lymphohistiocytosis type 4 (FHL4). Pediatr Blood Cancer. 2011;56(4):654-657.

50. Enders A, Zieger B, Schwarz K, et al. Lethal hemophagocytic lymphohistiocytosis in HermanskyPudlak syndrome type II. Blood. 2006;108(1):81 87 